\title{
Mutual contacts and lexical relations among the Finnic varieties of western Ingria and northeastern Estonia
}

\begin{abstract}
The aim of this article is 1) to describe the historical language contact situation between the genetically closely related Finnic varieties of western Ingria, 2) to give examples of the numerous loanwords originating from mutual contacts among local Finnic varieties as well as areal diffusion, and 3) to discuss the method of investigating contacts and borrowing among closely related varieties. The data are taken from old dialectal materials published in vocabularies and dictionaries as well as preserved in archives. The words that are analysed and discussed etymologically in more detail are drawn from Vote, Ingrian, and Estonian. Although it is often difficult to confirm the direction of borrowing among closely related varieties, I seek to determine the direction of diffusion in the varieties whose development cannot be described merely in terms of a traditional binary family tree model. Examples of mutual borrowing between Vote, Ingrian, Estonian, and Finnish are presented. Estonian loanwords in Vote and Ingrian can usually be recognised by their distribution. Most vocabulary originating as loans (in Vote, Ingrian, and Estonian) has been borrowed from Finnish. Loans in both Vote and Estonian often have a distribution not only in Ingrian but also in Finnish. Because of the phonetic similarity of these varieties, the donor variety usually cannot be defined. Vote loanwords occur only sporadically in Ingrian and Estonian: they may also form a substratum.
\end{abstract}

1. This study is written as a part of the research project "Language change in multilingual Finnic", funded by the Kone Foundation. 
The speakers of Finnic varieties in western Ingria used to live in old rural communities with long-term multilingualism, villages with a mixed population, and vague language boundaries. The arrival of new inhabitants from the countries, which ruled this area and the foundation of St. Petersburg in 1703 changed the ethnographic balance between different peoples in Ingria. This increased linguistic diversity and altered the hierarchy of the languages leading gradually to accelerating language and identity shift of the local peoples of Ingria.

Key words language contact, loanwords, etymology, dialectology, family-internal borrowing, receptive multilingualism, Vote, Ingrian, Estonian, Ingrian Finnish 


\section{Introduction}

The vocabulary of the Finnic varieties in western Ingria and northeastern Estonia reflects the historical language contact situation of the area in several ways. The closely related Finnic varieties spoken in the area are Vote, Ingrian, Estonian, and Ingrian Finnish. When speaking about these, I use the word "variety" instead of "language" in order to stress the fact that their situation in their traditional speech areas resembles more a dialect continuum, especially when it comes to Vote and Ingrian.

The traditional settlements of speakers of Vote and Ingrian were once located in western Ingria, the southeastern coastal area of the Gulf of Finland between the Narva River and the present-day metropolis of St. Petersburg. At the beginning of the $18^{\text {th }}$ century, St. Petersburg was established at a location that had been an ancient trading centre of Finnic peoples. Over the centuries, both Russia and Sweden have governed the Ingrian area, whereas the local people have never formed a politically independent state there. In the $17^{\text {th }}$ century, Finnish speakers migrated to Ingria, and following the foundation of St. Petersburg in 1703 and the Treaty of Nystad in 1721, Russian migration increased considerably. The most recent Finnic-speaking newcomers, Estonian migrants, started to settle in the same area in the second half of the $19^{\text {th }}$ century. Historically, German was spoken in Ingria to some extent and presumably, though more temporarily, Swedish was as well.

The arrival of new inhabitants from the countries, which have historically dominated this region politically, changed the ethnographic balance between different peoples in Ingria. This increased linguistic diversity and altered the language hierarchy leading gradually to accelerating language and identity shift of the local peoples of Ingria. Vote and Ingrian speakers were plurilingual and some of their villages in the Vaipooli area (located in the Lower Luga area), namely Jõgõperä, Liivtšülä, Luuditsa, and Rajo, had a mixed population.

In the easternmost Estonian parish of Vaivara there were also contacts between Estonians and speakers of Vote, Ingrian, and Finnish. The fishermen in the Vaipooli area met other fishermen speaking other Finnic varieties. (Ariste 1968: 14; 1981: 52-59, 79.) Presumably, Vote was once spoken across a wider area than in the $19^{\text {th }}$ and 


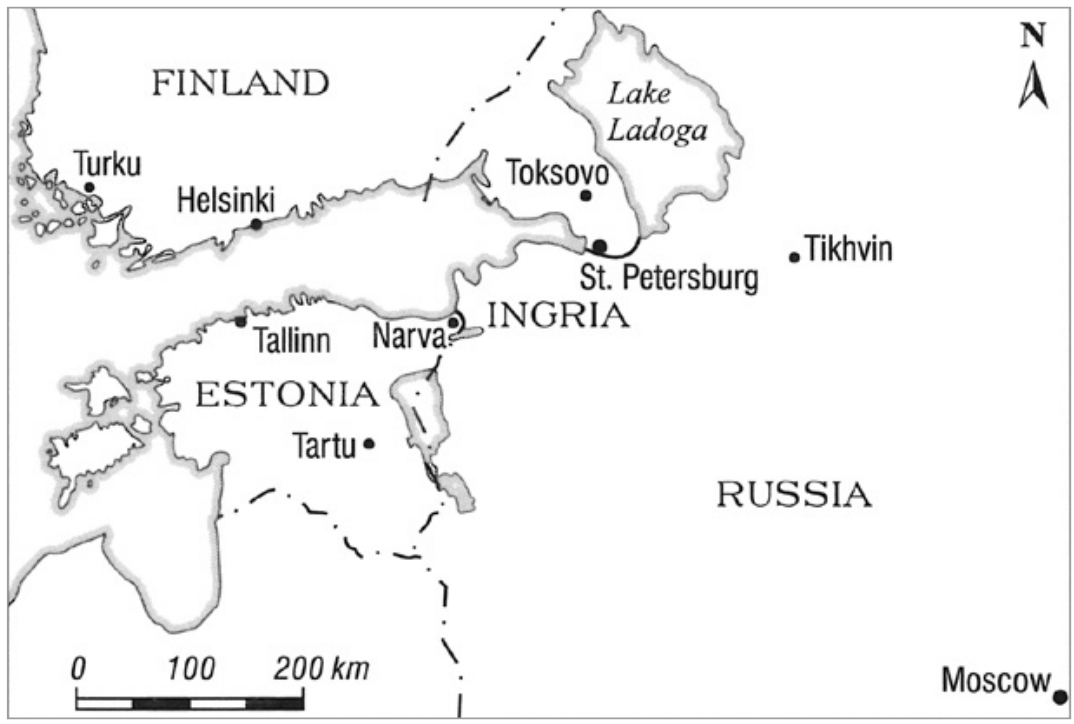

Map 1. The location of Ingria. Map from the back cover of Teinonen \& Virtanen (eds, 1999).

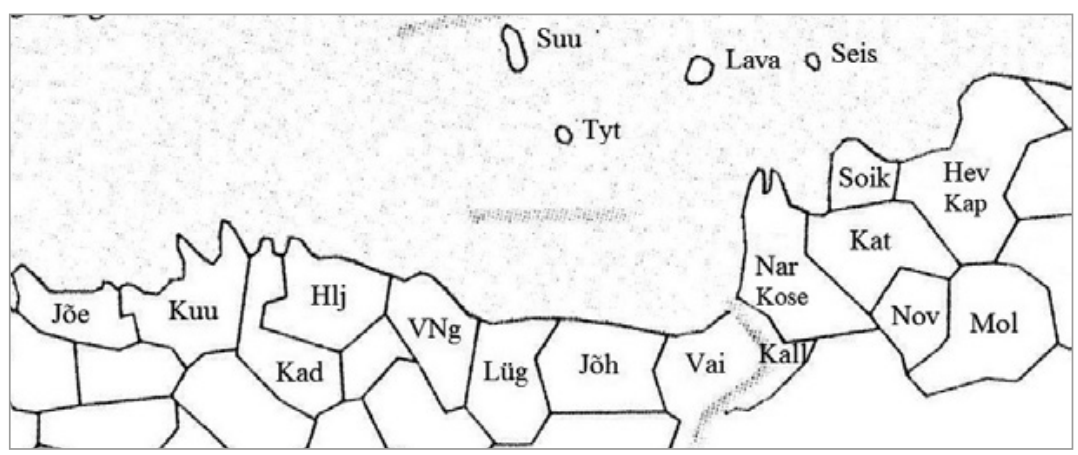

Map 2. Parishes in northeastern Estonia and western Ingria, and the Gulf of Finland islands. Map base from ALFE, markings by the author. Estonian parishes: Jõelähtme, Kuusalu, Kadrina, Haljala, Viru-Nigula, Lüganuse, Jõhvi, Vaivara. Finnish parishes in Ingria: Kallivere, [Kosemkina]2 , [Narvusi], [Kattila], [Soikkola], [Kaprio], [Hevaa], Novasolkka, Moloskovitsa. Finnish islands: Suursaari, Tytärsaari, Lavansaari, Seiskari. Vaipooli is located at the head of the bay in the parish of Kattila.

2. Finnish was not the main Finnic language in parishes written in [square brackets]. 
$20^{\text {th }}$ centuries and speakers of Vote lived alongside Estonian speakers in the present-day Vaivara region and also somewhat more to the south (Ariste 1965a: 110; 1965b: 92; Ernits 2005: 82, 83). Ingrian, on the other hand, is supposed to have been spoken as far as the present-day location of St. Petersburg and even to the Sestra River on the southern Karelian Isthmus as well as to the Nazija River in the east (Ernits 2007: 13).

\section{Hypotheses and aims}

My main hypothesis is that there are numerous loanwords originating from mutual contacts among local Finnic varieties; however, among closely related varieties it is often difficult to define the direction of borrowing. Nevertheless, the main aim is to find the origin of shared words, which in some of these Finnic varieties result from areal diffusion rather than descending directly from the common protolanguage. Furthermore, I seek to determine the direction of the diffusion and to reconstruct the language contact situation in Ingria in the $19^{\text {th }}$ and $20^{\text {th }}$ centuries.

This article has a twohold objective. In section 6, I describe the historical sociolinguistic situation in western Ingria, as this has not been done to this extent before. The data are collected from various contemporary writings. Section 7 deals with vocabulary and is divided into two parts. I have gathered all the words with at least two Finnic donor varieties found in previous studies and present them in the first part of the section. The latter part of the section is an attempt to describe the method of investigating mutual borrowing between closely related varieties by analysing eight selected words. My aim is to make the method more transparent and, if possible, to develop it somewhat. 


\section{Data and methods}

The empirical part of the current article is based on old dialectal word materials on all Finnic varieties published in vocabularies and dictionaries. In the case of Estonian and Finnish, the materials are still partly unpublished and are stored in archives. The materials were mostly collected between the beginning of the $20^{\text {th }}$ century and the 1970 s and they represent the situation of these varieties at a point when the development of multilingualism as well as language and identity shift had been ongoing for a long time. The analysis and detailed etymological discussion in this section focuses on words in Vote, Ingrian, and Estonian. Some words are discussed in more detail in order to make the method more transparent, because often older works in etymology and especially etymological dictionaries only give the conclusion, not the articulation leading to it.

The methods used are contact linguistics, etymology, lexicology as well as comparative dialectology. In the case of closely related varieties in contact, the classical criteria of etymology - phonology, semantics, and areal distribution - unfortunately are not sufficient alone. Recognising borrowing between closely related varieties is complicated, because there are only a limited amount of phonological features which can reveal loanwords. These are mainly found in Vote, for instance sound characteristics suggesting a loan origin (see, Suhonen 1986; Lauerma 1993: 160). Furthermore, defining the direction of diffusion or the precise loan source is often difficult and left unanswered in previous studies and vocabularies (Lauerma 1993; VKJo; VKKu; IMS).

When studying closely related varieties in contact, areal distribution becomes a more significant factor. Additionally, knowledge of the (cultural) history of the area in question and any sociolinguistic information is crucial, because the context of the contact has to be taken into consideration. As for the relationship between the Estonian Northeastern Coastal dialects and Finnish, Suhonen (1979: 360-364; 2000: 373) has pointed out that the most important criteria to be taken into consideration are the following: distributions of words, distributions of their meanings, contacts with neighbouring dialects, the origin of the possible loan original (especially in the case of a young loanword), inflectional types and categories, and the historical likelihood of it being a loan. All these factors suggest what is possible and plausible when investigating the direction of linguistic diffusion. 
As for the old sociolinguistic language contact situation, the existing principal resources are the writings of scholars who carried out their fieldwork in the $20^{\text {th }}$ century. These include fieldwork journals written on the trips as well as articles based on the impressions while out in the field but written and published later. My main sources are the posthumously published texts of Paul Ariste, who conducted his fieldwork in Ingria in 1942-1980. His diaries did not appear in print until 2005. Although Ariste conducted his work mostly during the Soviet years, he is known to have written in a way which really did not take Soviet censorship into consideration. Ariste's notes can therefore be considered relatively reliable and the fact that his journals were written while out in the field and immediately after the situations he describes makes them exceptionally important. Another source are the memoirs written by Lauri Kettunen about his fieldwork. Kettunen conducted fieldwork with Vote speakers in 1911-1915. His book, however, is written decades afterwards and it was most likely also edited prior to its publication in 1945. Therefore, it cannot be considered as authentic or reliable as Ariste's notes. My third source is the field journal of ethnologist Ilmar Talve from a trip in 1942, published in 1990. Talve translated the text from his native Estonian into Finnish before publishing it. He does not mention editing the text and it has maintained its travel journal style.

The historical mutual contacts of genetically closely related Finnic varieties have received little attention in modern Finno-Ugrian research. These three doctoral dissertations on morphology and phonology are the only larger existing works addressing this topic: Helka Riionheimo (2007) has studied the effects of contacts with Estonian in the past tense formation of Ingrian Finnish speakers living in Estonia, Ossi Kokko (2007) investigated the use of some cases in the speech of Ingrian Finnish speakers living mostly in Estonia, and Petri Lauerma's (1993) dissertation focuses on Vote vowel harmony, but also examines loanwords with both Finnic and Russian origin (especially pp. 165-192). Viitso (1993: 526) has considered this study to be of great importance for the study of Vote etymology. I am currently conducting lexical research in the field for my doctoral dissertation (a monograph in Finnish) on the language contact situation in western Ingria and northeastern Estonia from the viewpoint of internal borrowing within a language family. 


\section{The Finnic varieties analysed in this study and their speech areas in western Ingria}

In a broader context, the Finnic languages are closely related languages forming a subbranch of the Uralic language family. This article focuses on Vote, Ingrian, and Estonian with a special emphasis on the Estonian Northeastern Coastal and Eastern dialects.

\subsection{Vote}

Vote was spoken almost exclusively in western Ingria. Vote is traditionally considered to have four dialects: Western, Eastern, Kukkuzi, and Krevin Vote (see Map 3; classical division of the dialects Kettunen 1915; Heinsoo 1998: 19-22; VKS). Western Vote, as the largest subdialect, was spoken over the most extensive area. Modern research divides Western Vote into two groups: Central Vote, which was spoken in the Kattila region, and Lower Luga Vote, which is still spoken by a couple of elderly people in the villages with a mixed population, such as Jõgõperä, Liivtšülä, Luuditsa, and Rajo (Ernits 2005: 77; Muslimov 2005; Markus \& Rozhanskiy 2011a; Kuznetsova et al. 2015: 130). In the Finnish tradition, these groups have been referred to as the Kattila and Vaipooli (or Vainpuoli in Finnish) dialects. Eastern Vote was spoken in the villages of Itšäpäivä, Mahu, Iivanaisi, Kliimettina, Koslova, and Kaprio. When a particular word occurs in the eastern area then it can be considered old and therefore especially noteworthy. The Eastern dialect died out in the 1970s. Kukkuzi Vote spoken in Kukkuzi village is, in fact, a mixed language: it has an Ingrian phonetic and lexical superstrate with a Vote grammatical base (Suhonen 1985; Muslimov 2005; Markus \& Rozhanskiy 2011b; 2012). Krevin was the dialect of the Vote speakers who were relocated to Latvia in the $15^{\text {th }}$ century and which became extinct during the $19^{\text {th }}$ century. There is only a small amount of material on this variety, but it is important for investigating the history and earlier stages of development of Vote. 


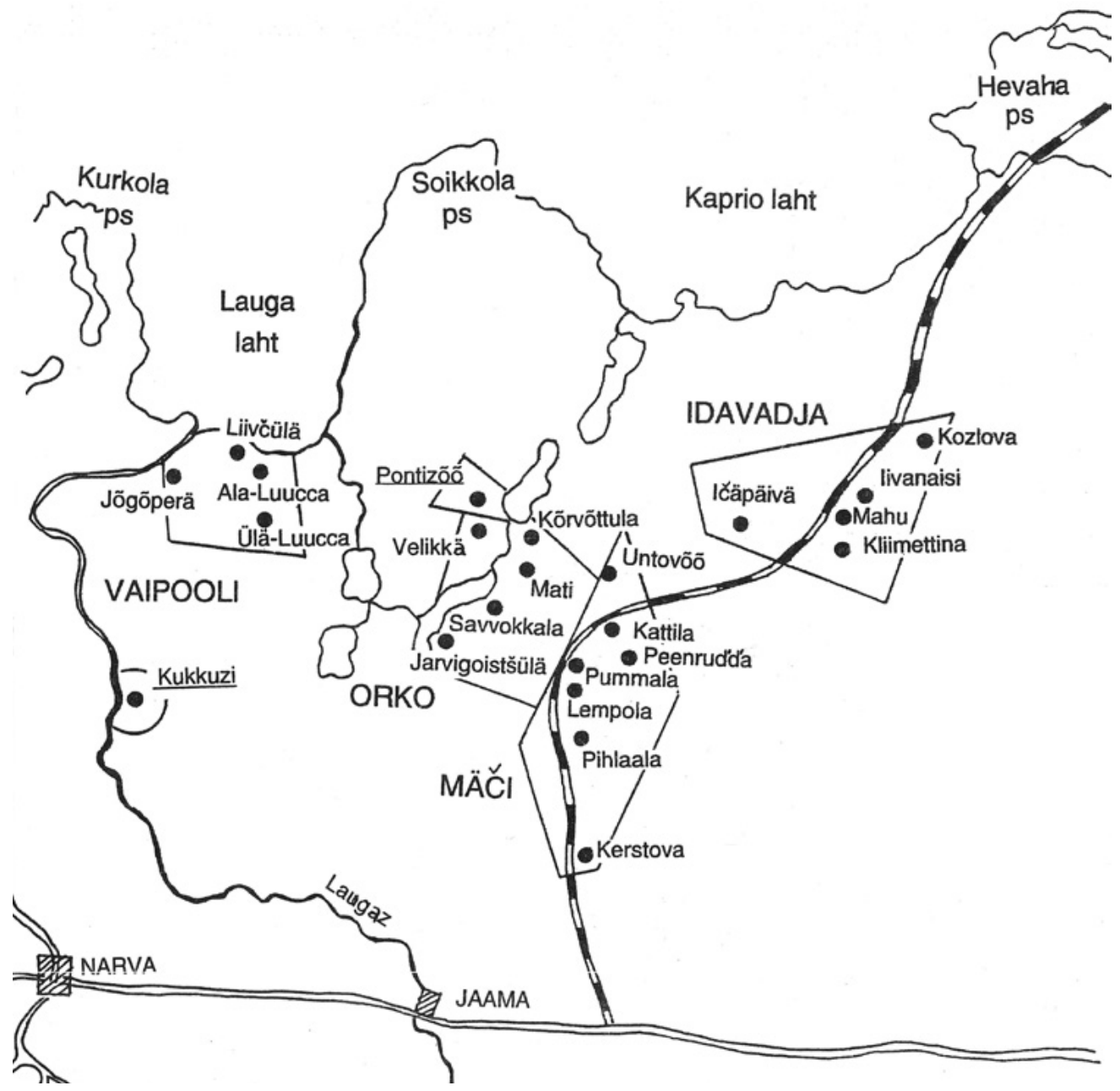

Map 3. Dialect areas of Vote and locations of villages. Extracted from the map by Tiit-Rein Viitso in Heinsoo (1998: 28). Idavadja = Eastern Vote. The Kattila area is divided into the Orko 'valley' and Mäči (= Mätši) 'hill' areas. Rajo is not marked on the map but it is located west of Jõgõperä on the same side of the Luga River. Liivčülä = Liivtšülä, Luucca = Luuditsa, lčäpäivä = Itšäpäivä. Laugaz = Luga River; Jaama $=$ Kingissepp. 


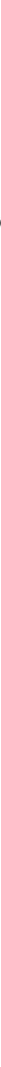

\subsection{Ingrian}

Ingrian has four main dialects: Lower Luga, Soikkola, Hevaa, and Oredež Ingrian (see Map 4; classical division of the dialects Porkka 188533; Laanest 1961; Nirvi 1961; 1971). Lower Luga Ingrian is still spoken by some elderly people along the lower course of the Luga River (and a mixed Finnish/Ingrian variety partly on the Kurkola peninsula (Kuznetsova et al. 2015: 131)). Soikkola Ingrian is spoken by some elderly people on the Soikkola peninsula, Hevaa Ingrian was spoken in the Hevaa River area, and Oredež Ingrian was spoken along the upper

3. Although, according to Porkka (1885: 17-18), the Lower Luga dialect is not a dialect of Ingrian. For criticism, see Laanest (1961: 200-202). 
course of the Luga River. The latter dialect is only fragmentarily documented, but it may be useful to research, as it could have preserved old vocabulary, which in other dialects of Ingrian may have been replaced with words from Ingrian Finnish dialects (Laanest 1970: 109). It has been assumed that Oredež Ingrian was formed when speakers of Ingrian fled the Swedish regime to the distant Oredež area in the $17^{\text {th }}$ century.

\subsection{Estonian}

Estonian was spoken throughout all of Ingria at the beginning of the $20^{\text {th }}$ century. The areas from which the Estonian-speaking immigrants moved to Ingria remain unclear, but it is likely that they came from all over the Estonian-speaking region. Estonian was spoken in western Ingria in the Kattila region and surrounding areas by over 2000 people at the beginning of the $20^{\text {th }}$ century, at least in the Vote villages of Itšäpäivä (in the Eastern Vote area), Jarvikoištšülä, Kõrvõttula, Mati, Pummala, and in the mixed population Vote villages of the Lower Luga region (Jõgõperä, Liivtšülä, Luuditsa, Rajo, and Kukkuzi) (Ariste 1987: $21-30 ; 1998: 15-16)$. At the end of the $19^{\text {th }}$ century, in some parishes in western Ingria even a third of the inhabitants were speakers of Estonian (Hakamies 1991: 201; repeated by Leskinen 1995: 172). There were already $64116^{4}$ Estonians in Ingria in 1897 according to the population census conducted in Russia that year. According to Ariste (1998: $15)$, the contacts between speakers of Estonian and Vote did not become intensive until the second half of the $20^{\text {th }}$ century. According to Muslimov, the largest number of Estonians lived in Novasolkka ${ }^{5}$ parish (Mehmet Muslimov, p.c. 16 \& 17 October 2015; see Map 6). Speakers

4. Of which, 12238 in the city of St. Petersburg.

5. Muslimov has had Estonian language consultants in at minimum the following villages in Ingria: Sakkola, Novesi, Zapalje, Ivanovskoje, Tikanpesä, Kattila, Kupanitsa, Viron-Priiskova (Rus. Krasnaja-Priiskova, not marked on the Finnish road map of Ingria from 1992 (compiled by Roland Randefelt) but located between Vennäin-Priiskova and Hakuli), Lopitsa, Moloskovitsa, Spankkova, Serepetta, Muhovitsa, Edasi (an Estonian kolkhoz in Kikkeri), Uusi-Hinkkala (near Spankkova), Markkusi (Rus. Marguzi), Simetsa (a village founded by Estonians), Arokylä (Rus. Ara-), Reskutsa (Rus. Treskovitsa), Marvitsa, Suur-Rutja or Pien-Rutja (in either of the villages), Raakovitsa, Saappola, Prömpeli, Mustapää, Keskikylä (Rus. Srednje, not marked on the map but located northeast from Klenna roughly by the number 12 on the Finnish road map of Ingria), Ivanskoi, and possibly Asikka (Mehmet Muslimov, p.c. 17 October 2015). 


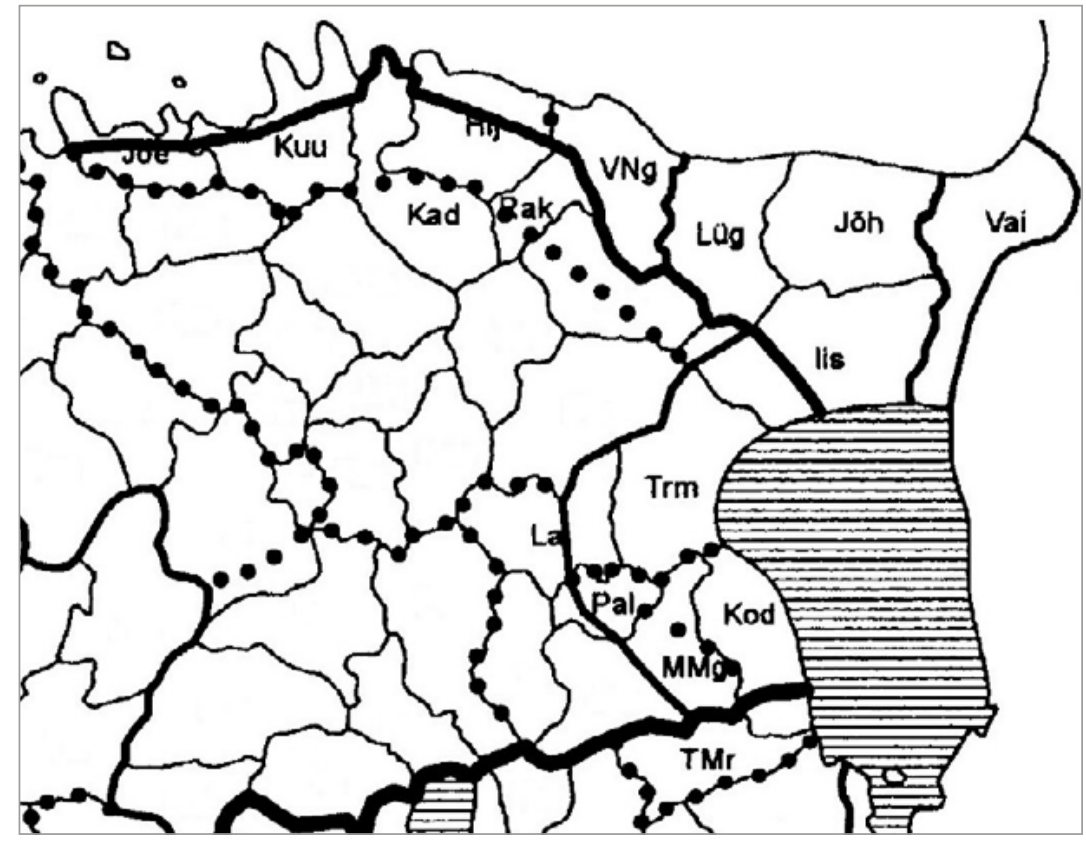

Map 5. Estonian dialect areas and parishes in the northeastern corner of Estonia according to Pajusalu (1999). Map extracted from the map in Pajusalu et al. (2009: 56). The Estonian Northeastern Coastal dialects were spoken in the parishes from Jõelähtme to lisaku and Vaivara (Jõe, Kuu, Hlj, VNg, Lüg, Jõh, lis (the abbreviation for the dialect is lisR), Vai); the Estonian Eastern dialect in the parishes from lisaku to MaarjaMagdaleena (lis, Trm, Kod, MMg, Pal, Lai). Kadrina and Rakvere (Kad, Rak) belong to the Central dialect, Tartu-Maarja (TMr) and a part of Kodavere and Maarja-Magdaleena (the abbreviations for the dialects are KodT, MMgT) belong to the Tartu dialect.

of Vote, Ingrian, and Finnish came in contact with speakers of Estonian mostly in or nearby the city of Narva in eastern Estonia, at the NarvaJõesuu harbour, and in the city of Jaama ${ }^{6}$ in western Ingria, where the Estonian congregation had 4500 members. Inhabitants of Ingria also worked in these places and went there to trade goods. (Ariste 1981: 52; 1987: 30; 1998: 17; Talve 1990: 64.) Conceivably, the dialect of Vaivara parish is of special importance (Viitso 1993: 524). It has been conjectured that an old Vote-speaking population in eastern Estonia has left traces in the vocabulary of the Eastern and Northeastern Coastal

6. Jamburg in German, nowadays Kingissepp. 
dialects of Estonian and as a substrate in place names (Ariste 1965a: 109-110; 1965b: 92; Pall 1969: 6-7, 261-263, 303-304; 1970: 12-17; 1977: 16, 228-230). However, this assumption has been made mostly on the basis of onomastics and archaelogy and has been criticised by Grünthal (1997: 113-149, especially 119-121).

The main Estonian dialects historically in contact with Vote and Ingrian are the Northeastern Coastal and Eastern dialects of Estonian (see Map 5). The Estonian Northeastern Coastal dialects were spoken in the parishes of Jõelähtme, Kuusalu, Haljala, Viru-Nigula, Lüganuse, Jõhvi, Iisaku, and Vaivara; the Estonian Eastern dialect was spoken in the parishes Iisaku, Torma, Kodavere, Maarja-Magdaleena, Palamuse, and Laiuse. The Northeastern Coastal dialects are divided in the Coast dialect (Jõe, Kuu, Hlj, Vai) and the Alutaguse dialect or Northeast dialect (VNg, Lüg, Jõh, IisR) (Pajusalu et al. 2012: 246).

\section{Languages in contact with the Finnic varieties examined in this study}

Ingrian Finnish, that is, the Finnish dialects spoken in Ingrian territory, is considered a variety with close contacts with the other Finnic varieties of this area. Russian, although not examined in this article, also had a substantial effect on the Finnic varieties, while German and Swedish did not.

\subsection{Ingrian Finnish and other dialects of Finnish}

Ingrian Finnish was the largest Finnic variety in Ingria in terms of number of speakers and was spoken across this entire area. Only in western Ingria was Finnish not the main Finnic variety. (Saloheimo 1991: 81.) Ingrian Finnish dialects are classified as Southeastern dialects of Finnish. The speakers of Ingrian Finnish had originally moved to Ingria in the $17^{\text {th }}$ century after the Treaty of Stolbovo in 1617, when Sweden began to colonise Ingria. The newcomers from Äyräpää parish on the Karelian Isthmus were called äyrämöiset, while the others, whose precise origin is harder to define and is not discussed here, were called savakot and the Narvusi Lutherans. The main Ingrian Finnish 


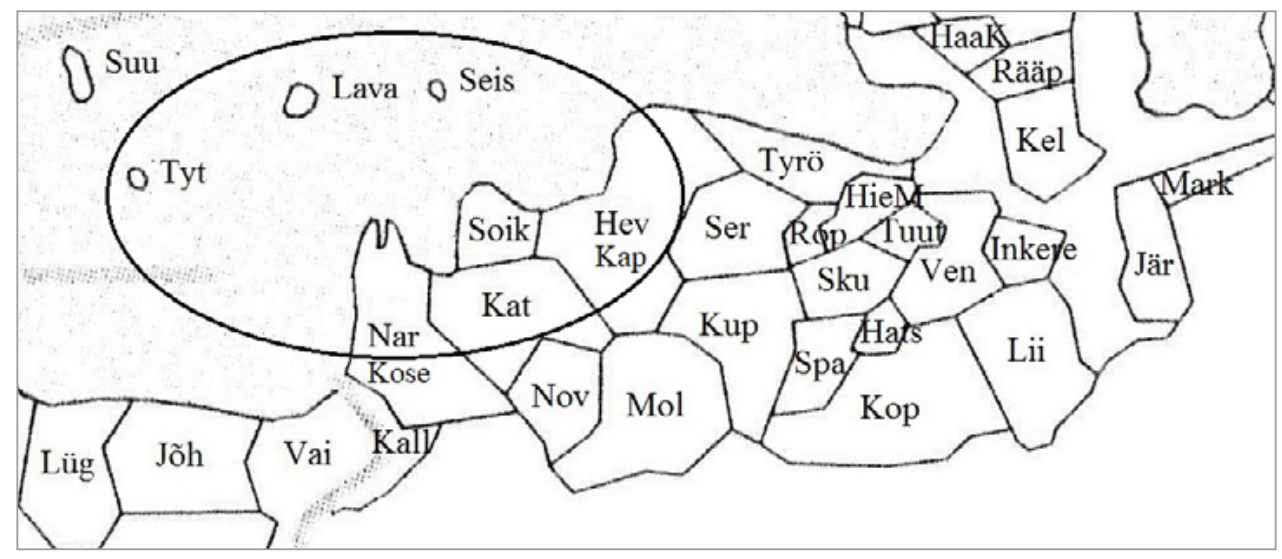

Map 6. Ingrian Finnish dialects (northern parishes only partially shown) according to SMS. Map base from ALFE, markings by the author. The dialect spoken on Suursaari (Suu) belonged to the Kymi dialects; the dialects spoken on Tytärsaari, Lavansaari, and Seiskari (Tyt, Lava, Seis) belonged to the Southeastern dialects (South Karelian dialects) of Finnish proper. Dialects from Lüganuse to Vaivara are dialects of Estonian. The Ingrian Finnish dialects spoken in Kallivere ${ }^{7}$, Kosemkina, Narvusi ${ }^{8}$, Kattila, Soikkola, Kaprio, Hevaa, Novasolkka, and Moloskovitsa (Kall, Kose, Nar, Kat, Soik, Kap, Hev, Nov, Mol) are considered the western group of Ingrian Finnish by Muslimov (2009), followed by Kuznetsova et al. (2015: 132-133). Kosemkina, Narvusi, Kattila, Soikkola, Kaprio, Hevaa are parishes where Finnish was not the main variety. Vote speakers lived in the parishes of Narvusi, Kattila, Hevaa; Ingrian speakers lived in the parishes of Narvusi, Kattila (in the Vaipooli area), Soikkola, and Hevaa. The circled area is the main area - aside from the cities - where Vote and Ingrian speakers would encounter each other most: on the islands this was in connection with fishing, on the mainland it was due to the location of the areas in which they lived.

7. Interestingly, in Kuznetsova et al. (2015: 133), Kallivere is not mentioned in the discussion of Ingrian Finnish dialects of western Ingria. Tyrö is regarded as a western Ingrian Finnish dialect.

8. Kuznetsova et al. (2015: 133) call the Ingrian Finnish dialect spoken in Narvusi parish the Lower Luga dialect. In fact, Kettunen (1930: 191, 193, 194, 195) also writes in Finnish about the [Finnish] dialect of the Lower Lugans, the dialect of (the Lutherans of) Lower Luga, the [dialect] group of Lower Luga, the Lower Lugans, and the Lower Luga dialect. 
dialects were the äyrämöis-dialects, spoken mainly along the coast of Ingria, and savakko-dialects, spoken mainly inland. The smallest dialect, the Narvusi or Kosemkina dialect, also classified as the Finnish dialects of Kurkola and Rosona (in Leppik 1966; 1972; 1973; 1975 and Mägiste 1925), is strongly influenced by the other Finnic varieties of the area. The background of the Finnish dialects of Ingria was not uniform and Ingrian Finnish in the $20^{\text {th }}$ century was already a fusion of different dialects. (Leskinen 1991: 230; 1995: 170-171; Savijärvi 1996a: 8-10; Riionheimo 2007: footnote 8, 18). Speakers of other Southeastern dialects of Finnish were encountered while fishing on Seiskari, Lavansaari, and Tytärsaari - islands in the Gulf of Finland. In St. Petersburg, there likely were speakers of even more Finnish varieties, for example the Southern Karelian dialects of Finnish. For the Ingrian Finnish dialects in western Ingria, see Map 6.

\subsection{Other languages of Ingria}

The most widely spoken language in Ingrian territory was, of course, Russian. Other Indo-European languages also have been spoken in this area: Hakamies (1991: 200) conjectures that as 6600 of the 11490 Germans in Ingria in 1848 lived in Kronstadt and Narva (data by von Köppen $1849 ; 1867)$, there were relatively few Germans in the countryside and that they did not have contacts with or impact on speakers of the Finnic varieties spoken there. Presumably, at one point there were also Swedish speakers in Ingria, at least Krjukov (1993 [1987]: 24) mentions that the Swedes and Germans who moved to Ingria in the $17^{\text {th }}$ century, assimilated into other Lutherans (i.e., Finnish- and Estonian-speaking people) in the $18^{\text {th }}$ and $19^{\text {th }}$ centuries. For example, the Swedish-speaking chronicler Thomas Hiärne (16381678) of Livonia was born in Skuoritsa, central Ingria.

In comparison to the number of speakers of German, there were 5148 Votes, 17800 Ingrians, 76069 Finns, and 3522 Estonians living in Ingria in 1848 when the peoples of Ingria were documented for the first time by ethnologist Peter von Köppen (von Köppen 1867: 20, 41, $92,105,114)$. 


\section{The historical sociolinguistic situation in western Ingria}

Sociolinguistically, in these Finnic-speaking rural communities, the language boundaries were extremely vague. In fact, both Vote and Ingrian speakers have repeatedly expressed the opinion that their dialects are dialects of the same language (Ariste 2005: 47).

\subsection{Plurilingualism and receptive multilingualism}

In the Vaipooli area in western Ingria, the plurilingualism of the last speakers of Vote and Ingrian can be described as receptive multilingualism: they used their own language when communicating with each other (Kettunen 1945: 237; Ariste 1957: 122; 1958: 148; 1981: 58). The traditional use of the different Saami languages was also like this (Pasanen 2015), and using one's own language for contacts between speakers of the Saami languages and speakers of Finnish was a traditional model in the Saami area (M. Aikio 1988: 73-74, 77). These languages are, in principle, genetically related but not mutually intelligible, and receptive multilingualism is based on speakers living in the same area for a long time. Due to a shared basic vocabulary and grammar the closely related Finnic varieties have mutual intelligibility to some extent. However, receptive multilingualism in western Ingria was based on and very much supported by the fact that speakers of the different Finnic varieties of this region had lived for an extended period of time alongside each other in an area consisting of villages with mixed population and long-term multilingualism. Ariste (2005: 69) also notes that the Ingrians, who had had more contact with either Finnish-speaking or Estonian-speaking people, better understood the language in question. Talve (1990: 64) notes that in 1942, almost all the Votes in Vaipooli understood Estonian, because there had been Estonian inhabitants in Vaipooli. At the end of the $19^{\text {th }}$ century, when even a third of the inhabitants were Estonian speakers in some parishes in western Ingria, Finnish speakers in western Ingria would even read Estonian books when they did not have Finnish books (Hakamies 1991: 201). ${ }^{9}$

9. On receptive multilingualism in contemporary Finnish-Estonian interaction see Härmävaara $(2013 ; 2014 ; 2017$; forthcoming). However, in spite of the studied languages being closely related, the situation of Finns and Estonians brought up in 


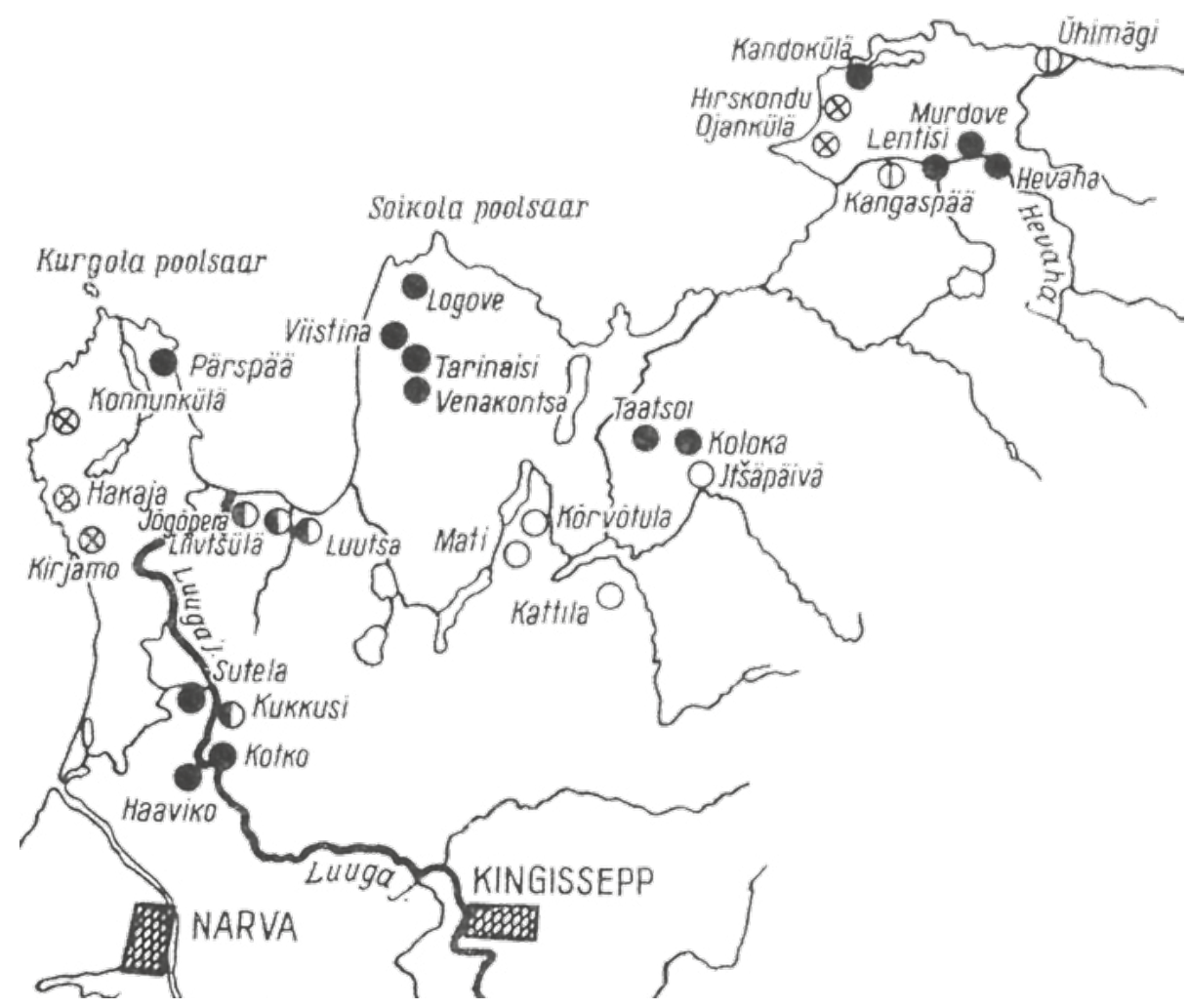

Map 7. Finnic varieties spoken in the villages of western Ingria (extracted from the map in Laanest 1964: 4). The map shows the mixed Vote- and Ingrian-speaking villages in the Lower Luga area. Otherwise, the map is prepared from the point of view of the Ingrian variety, and therefore some of the Vote-speaking villages and many of the Finnish-speaking villages are left unmarked, for example, Lempola, Pummala, and Mahu, where both Vote and Finnish were spoken. Luutsa = Luuditsa. Luuga j. = Luga River; Kingissepp = Jaama.

Explanations: Ingrian $\mid \mathrm{O}$ Vote $\mid \otimes$ Finnish $\mid \mathbf{O}$ Vote \& Ingrian $\mid$ ( Finnish \& Ingrian

In fact, many speakers of Finnic varieties - especially the Votes and Ingrians - in western Ingria also spoke each other's varieties. According to Kettunen (1930 [1915]: 7), this was the case for Vote and Finnish speakers in Lempola, Pummala, and Mahu. In Luuditsa (Luucca, Luutsa

their own countries and then trying to interact with one another can not be compared with the situation of western Ingria directly. 
on maps $3 \& 7$ ), there lived "truly bilingual Votes", who were equally proficient in Ingrian and Vote (Ariste 1981: 62). In Soikkola, Finnish speakers could understand Vote (M. Paulaharju 2010: 142 [original source S. Paulaharju 1915]). However, the data available are somewhat ambiguous. For example, it has been said that in the past, speakers of these four different Finnic languages usually did not learn each other's varieties because they got along by only speaking their own (Ariste 1957: 122). In the $20^{\text {th }}$ century, Ingrian became the more common language of communication between Vote and Ingrian speakers, because there were more speakers of the latter variety. Ariste states that the last speakers of Vote in the Vaipooli area knew Ingrian but not vice versa. (Ariste 1981: 58.) It has also been said that services in Lutheran churches also had to be held in Estonian, because Estonian speakers did not understand Finnish (Kettunen 1957: 126-127); however, this is likely due to the fact that speakers of Estonian were the most recent immigrants to the area.

\subsection{Language prestige and asymmetry of contacts}

The prestige of Russian, the urban and a fully developed languge used in all domains, was high, whereas the rural languages Vote and Ingrian had neither official status nor literary use and were used only in informal domains. Russian, on the other hand, was the language of administration, education, and the Orthodox church ${ }^{10}$. Finnish was also a rural language in Ingria, but as the major Finnic variety it had higher prestige than the smaller Finnic varieties also because of its use in the Lutheran church and later in the Finnish schools of Ingria. Its use among speakers of Vote and Ingrian - considered "Finns" by the Lutheran priests at one time - had even been supported by any means possible in the $17^{\text {th }}$ century (Savijärvi 1998: 274).

Generally speaking, the language contacts and use of local varieties has been asymmetric, as also Markus \& Rozhanskiy (2010; 2013) have pointed out in their studies of Vote and Ingrian. These two Finnic varieties had the lowest prestige in Ingria; however, Ingrian was still in a more powerful position. Ingrian had more speakers and there was

10. The language used in masses held at the Orthodox church was, of course, Church Slavic, which was not intelligible (even) for speakers of Russian. However, the church was considered the Russian church without a doubt. 


\begin{tabular}{|c|c|c|c|c|}
\hline $\begin{array}{c}\text { low } \\
\text { Vote }\end{array}$ & Ingrian & $\begin{array}{l}\text { PRESTIGE } \\
\text { Estonian }\end{array}$ & Finnish & $\begin{array}{l}\text { Russian } \\
\text { R - - high }\end{array}$ \\
\hline $\begin{array}{l}\text { smallest rural } \\
\text { language }\end{array}$ & $\begin{array}{c}\text { rural } \\
\text { language }\end{array}$ & $\begin{array}{l}\text { newest rural } \\
\text { language }\end{array}$ & $\begin{array}{c}\text { largest rural } \\
\text { language }\end{array}$ & $\begin{array}{c}\text { urban } \\
\text { language }\end{array}$ \\
\hline $\begin{array}{l}\text { no standard } \\
\text { language }\end{array}$ & $\begin{array}{l}\text { no standard } \\
\text { language }\end{array}$ & $\begin{array}{l}\text { standard } \\
\text { language }\end{array}$ & $\begin{array}{l}\text { standard } \\
\text { language }\end{array}$ & $\begin{array}{l}\text { standard } \\
\text { language }\end{array}$ \\
\hline $\begin{array}{c}\text { no literary } \\
\text { use }\end{array}$ & $\begin{array}{c}\text { no literary } \\
\text { use* }^{*}\end{array}$ & $\begin{array}{l}\text { (literary use } \\
\text { in Estonia)** }\end{array}$ & $\begin{array}{l}\text { education, } \\
\text { media }\end{array}$ & $\begin{array}{l}\text { education, } \\
\text { media }\end{array}$ \\
\hline $\begin{array}{l}\text { no adminis- } \\
\text { tration }\end{array}$ & $\begin{array}{l}\text { no adminis- } \\
\text { tration }\end{array}$ & $\begin{array}{l}\text { no adminis- } \\
\text { tration }\end{array}$ & $\begin{array}{l}\text { (administr. } \\
\text { in Finland) }\end{array}$ & $\begin{array}{c}\text { adminis- } \\
\text { tration }\end{array}$ \\
\hline no church & no church & no church & $\begin{array}{l}\text { Lutheran } \\
\text { church }\end{array}$ & $\begin{array}{l}\text { Orthodox } \\
\text { church }\end{array}$ \\
\hline
\end{tabular}

Table 1. Prestige, status, and use of the languages of western Ingria at the beginning of the $20^{\text {th }}$ century.

* With the exception of an attempt in the 1930s.

** In schools in so-called Estonian Ingria in the 1920s and 1930s.

even an attempt to create a standard language and to use it as a language of instruction in schools in the 1930s. In his often quoted article, Tsvetkov (1925: 43) notes that when an Ingrian-speaking wife was brought to a Vote-speaking household, the whole family shifted their language to Ingrian. Though, most likely they shifted to a convergent variety, as suggested by Fedor Rozhanskiy (p.c. 20 August 2015; more about this variety in Rozhanskiy \& Markus 2013: 230; 2014). According to Rozhanskiy, the women were mostly from Soikkola, and, of course, the Ingrian spoken in the Lower Luga area is not the Soikkola variety. It was also typical for speakers of Vote to speak Ingrian with speakers of Ingrian despite the fact that Ingrian-speakers knew Vote as well (Tsvetkov 1925: 43), but this also may have been a mixed variety. Vote was very rarely used with children. At the last stage, it has been reported that there were children in only two families speaking Vote with their Vote-speaking father and Ingrian with their Ingrian-speaking mother at the beginning of the $20^{\text {th }}$ century (Ariste 1968: 15; 2005: 98, 111, 112). Usually, Russian was preferred with children because it was believed that they would absolutely need Russian in the future.

Estonian, like Finnish, had a standard language and literary use. These languages had a status in their homelands which added to their 
status in Ingria, but the autochthonous languages of Ingria - Vote and Ingrian - were spoken only in Ingria. In so-called Estonian Ingria, a ten kilometre-wide strip on the eastern side of the Narva River, which was ceded to Estonia in 1920, the language of education was Estonian in 1922-1926 (in Kallivere, Vanaküla, Kullaküla) and in 1933-1940 (in Kallivere, Vanaküla) (Alenius 2015). However, the Finnic varieties in this article are examined as they were spoken during a period mostly during the middle of the $19^{\text {th }}$ century and this political development is more recent. In the case of Russian, the position of the dominant language should be discussed in more detail. Ultimately, political power guaranteed a more prestigious status for Russian.

\subsection{Ethnic and linguistic identities}

Accordingly, the ethnic and linguistic identities of the speakers of Vote and Ingrian were vague: the main factor in defining identity was religion, which meant that local people could define themselves as Russian because of their "Russian" religion. The Greek Orthodox religion played a significant role and it in fact was the main connective factor between the speakers of Vote and Ingrian and the Russians. In spite of their language, every person in the Orthodox faith could be considered a Russian. For example, mixed marriages were allowed only with other Orthodox people, not with the Finnish-speaking Lutheran people. Being Russian became more prestigious as time went on and having a Finnic ethnic identity might even have been dangerous after the Russian Revolution - at least if it was written in one's passport. Usually speakers of Vote marked their ethnicity as Ingrian (ижореи, ижорка in Russian) and nationality as Russian when answering cencuses because they simply did not have a Vote identity. Working in the cities, especially in St. Petersburg, contributed to the language shift to Russian. These facts led to a gradual assimilation where Ingrian speakers assimilated into the Russians as Vote speakers assimilated into both Ingrian speakers and the Russians. (Tsvetkov 1925: 41-42, 44; Ariste 2005: 31, 40, 67, 74.) In 1967, Ariste's (2005: 104) language consultants were of the opinion that Vote and Ingrian were disappearing because of the deportations of their speakers to Finland and Russia during the war, which is also certainly true. 
One of the few means used for describing belonging to a particular Finnic group was a distinction Vote and Ingrian speakers would make. Namely, the verb used for 'speaking' is different: in Vote $p a$ jattaa, in Ingrian läkkää, and this difference was used to define the language of the other speaker. The terms pajattaja and läkkääjä, both meaning 'speaker', were used without the potential name of the language spoken. However, it seems that the speakers understood this difference to be dialectal. (Ariste 1981: 62; 2005: 66, 83, 92, 97, 124, $125,126,142$.) Another means for drawing this distinction was to use terms derived from local place names: names of villages, parts of villages, or village groups (Ariste 2005: 28, 30). On the other hand, some speakers have referred to songs in Finnic languages as Finnish songs in order to draw a distinction with Russian culture (Ariste 2005: 55). The adjectives Vo. soomalain, Ing. suumelain 'Finn' have been used for speakers of Finnish in Ingria, and people from Finland have been called Vo. soomõomaakko (approximately 'a person from Finland, Finlander') or even Vo. finn(i) (a Russian loanword). All Lutherans may also have been called Finns or "of Finnish belief" - also Estonians and Germans - because the Lutheran church was the Finnish church in Ingria. (Ariste 2005: 31-32; IMS s.v.; VK s.v.) One representative example is when on a field trip in 1942, Ariste asked in Vote if an old Russian man speaks Vote. The man answered in Russian: "Немного по лютерански говорю", 'I speak a little bit of Lutheran' (my translation and italicisation). (Ariste 2005: 37.) The concepts of language, nation, and religion were completely intermingled in Ingria.

\subsection{Language attitudes}

As for language attitudes, there has been very little, if any, awareness or interest among the speakers of the smallest Finnic varieties of Ingria - Vote and Ingrian - in their own local varieties or in raising their profile. In 1942, Ariste noted that Vote speakers were totally uninterested in and passive about the possibility of the extinction of their language. Ariste encountered only two language consultants who felt otherwise: a Vote-speaking consultant who despised her mother tongue and another consultant whom he classified as "a true Vote patriot". One would think that most likely not until the repressions would Vote and Ingrian 
speakers have underrated their mother tongue and called it "non-cultural" or "the language of calves" or "sheep" - and in cases where this occurred, this probably would have been due to mistreatment. However, it is interesting that in 1913 in Mahu, where Eastern Vote was spoken, Kettunen was told that fifty years earlier Vote had been spoken all over the village but then the speakers had suddenly begun to scorn their language. One reason for this might have been that unlike Finnish and Estonian, Vote had no standard language, as one speaker of Vote interviewed by Kettunen stated: "kammuga tšeeli, bõ õ tširjaa bõo pappia" 'such a language, no book, no priest' (my translation). This may sound slightly negative but can, nevertheless, be interpreted as a rather neutral statement concerning the situation of this variety. In any case, this development is likely to be somewhat earlier compared with developments in the western speech areas of Vote, which Ariste visited in 1942, because Eastern Vote died out already in the 1970s. (Kettunen 1945: 231; Ariste 2005: 43, 44, 65, 67, 74, 77, 87, 133.)

\subsection{Mixed varieties}

Ariste often describes the language of his consultants as a mixed language: Vote with Ingrian influence or even vice versa (Ariste 2005: $62,65,67,73,74-75,95,97,101,130,138,151,157)$. This reflects the nature of plurilingualism and its effects on idiolects. However, the question is, whether these varieties have always been mixed to some extent. Like all of the dialectologists conducting fieldwork at that time, Ariste also looked for speakers of the so-called "purest" language or dialect possible. This idealised concept does not really reflect reality, as no "pure" Vote-speaking or "pure" Ingrian-speaking communities have ever existed. A consultant might even say that someone speaks Vote, but during his conversations with the person in question Ariste might instead say that their idiolect is Ingrian. The Kukkuzi dialect of Vote is a topic of its own: it is a variety with substantial Ingrian influence on a Vote substrate, and it can be classified as a mixed language (Suhonen 1985; Muslimov 2005; Markus \& Rozhanskiy 2011b; 2012).

For more on the current situation of Ingrian Finnish, Ingrian, and Vote, see Rozhanskiy \& Markus (2019), in this volume, and Kuznetsova et al. (2015). 


\section{Vocabulary}

This section will discuss earlier studies dealing with mutual borrowing among Finnic varieties in Ingria. In the portion focusing on empirical research, word examples found in Vote, Ingrian, and also Estonian are discussed from an etymological perspective. Despite the presence of individual words in these varieties, these are examples of areal diffusion, not genetic inheritance. The words analysed here illustrate the etymologically most unambiguous cases, and are given here in order to describe the method of etymologising borrowing among closely related varieties. Each is categorised according to its probable donor variety. In earlier research, some have noted the senselessness of attempting to etymologise the direction of borrowing (Laakso in VKJo 1995: IV-V). This is likely true in many cases; however, with detailed and diligent work some proposals concerning the direction of borrowing can be posited using etymology.

\subsection{Earlier research}

In the research literature, some Finnic loanwords with a distribution across the three aforementioned varieties can be found. I have collected these from the literature and will present them here with English translations of their meanings (the translations from Finnish and Estonian into English are my own except for the translations from Söderman 1996).

\subsubsection{Research on Vote}

In his doctoral dissertation, Petri Lauerma (1993: 165-192) lists a total of 33 Ingrian, Finnish, or Estonian loans in Vote, which, according to him, have a distribution in both Ingrian and Estonian as well. However, I have already found wider Finnic distributions for some of the words he mentions. These will be dealt with later in the ongoing study. Words given by Lauerma are the following: 
Vo. ahteri 'stern (of a ship)', ennustā 'to predict', hame 'skirt', herttain 'warm-hearted, kind, sweet, good', heruttā 'to get a cow to increase its milk production when milking', kaneppi 'hemp' (< Est. Ariste 1941), kapteni 'captain', kena 'nice, beautiful, slender, vain', koer koera 'dog', koppeli koppeni 'pen (for animals)', kortteli 'apartment', kovera 'concave', kukerpalli 'somersault', lajenki 'load', lékuttā 'to swing', meistari 'master', murhe 'concern, worry, grief', omena 'potato', panekki 'a holiday during fast', paperi 'paper, document, note', pēntara 'bank, edge', puteli 'bottle', rehvata 'to reef', seilata 'to sail', seka 'mix', sekain 'messy', sekami 'messy', tehota 'to have an effect', trehvata 'to meet by accident, to hit sth', treijata 'to roll, to turn, to twist', venua 'to stretch', venuttā 'to stretch sth', vettus 'to get wet' (Lauerma 1993: 165-192).

Dmitri Tsvetkov's Vocabulary of the Joenperä (Jõgõperä) dialect of Vote (Vatjan kielen Joenperän murteen sanasto, VKJo 1995, edited by Johanna Laakso) presents 87 loans in Jõgõperä Vote from either Ingrian or Estonian. I have collected these from the VKJo reverse vocabulary compiled by Johanna Laakso. An asterisk in front of a word indicates that the word form is an assumed nominative or infinitive construed by the Finnish editor. The words are:

Vo. (J) āstaik 'year', āstaikõin 'yearling', bulli 'bull', bässi 'ram' (+Fi.), елизо̃лл 'to live', елиssa 'to live', halli 'grey', hallissua 'to grey', hapo 'sour', hapo-pīm 'sour milk, ?curd', hapo-rahk '?curd', haria 'to raise', huлkkua 'to wander around', huлkkujõ 'wanderer', huлkkumin 'wandering around', huntti 'wolf; seldom used: sluggard, idler, loiterer', hunttsu 'sluggard, idler, loiterer', hursti 'shroud, bed linen, sackcloth, tablecloth', kaiлиssa 'to hug', kалло̃ ' to pour (liquid)', kало̃ 'harsh, severe, rough (voice)', kapteni 'captain', kena 'beautiful, pretty, handsome, dandy', kenap 'more slender', kenassua 'to get beautiful, to get pretty', ketti 'chain', ketti-koir 'dog in chains', kihittä 'to chase away', kihutta 'to move, to lift, to throw (away), to speed', kihutuz 'speeding, throwing (away), removing', kikertäss 'to giggle, to trill, to warble', kīli 'wedge', kippua 'to tend to, to hurry, to try impatiently', kittsi 'small goat', kleitti 'dress', klinkissä 'to bolt', klinkittä 'to lock, ?to bolt', klinkittäss 'to get closed', kliykki 'bolt', kлoppia 'to pile, to stack, to heap up', kontturi 'office', krāmi 'thing(s), belongings', krāppi 'card, scraper', krāppia 'to scrape (leather), 
to scratch', kringeli 'pretzel', kȫkki 'kitchen', susti 'grand, beautiful, slender; joy, pleasure', лиstissi 'beautifully', *лиstiuz 'beauty', * лustivoitta 'to make beautiful', meisteri 'master', mekkiä 'to taste', *millin 'what kind of', narria 'to tease, to jibe, to mock, to slander', nikõrta 'to do joinery (woodwork)', passia 'to fit, to be sufficient', pekki 'lard', pikisell 'to squash, to squeeze, to press', pikissä 'to squash, to squeeze, to close', pikisüz 'squash, squeeze', polle 'apron', priski 'sturdy, healthy, good', pü-sūkkuri 'loaf sugar', rīvõtoi 'shameless, mean, obscene, disobedient, stubborn', runni 'heap (of pieces of ice blocks, stones)', rūn 'gelding', rūnõt 'to geld', rüto 'link (in a chain), a piece of glass, windowpane; diamonds (a suit in playing cards)', selettemin 'explaining, explanation', sūkkuri 'sugar', sūkkurīn 'sugary', sūkkur-līv(õ) 'granulated sugar', sūkkur-pä 'sugar loaf', taksi 'charge', tontti 'evil spirit, devil, brownie, hobgoblin', tōppi 'tankard (also as an unit of measure)', tōppīn 'a tankardful (as a measurement)', tramppia 'to stamp one's foot; to limp', tulli 'rowlock', turu 'market place', tükkü 'piece', tükküin 'in pieces', tükküitt ä 'by pieces', tükükkõin 'a small piece', vāgõn 'wooden plate, dish', vokki 'spinning wheel', värski 'fresh, raw' (all < Ing./Est.).

\subsubsection{Research on Ingrian}

In his Dictionary of Ingrian dialects (Inkeroismurteiden sanakirja, IMS 1971), R. E. Nirvi presents words borrowed into Ingrian from two other Finnic languages: 40 loans from Estonian or Vote and 34 from Estonian or Finnish. However, many of these words share the same stem. I have collected these words from the Reverse Vocabulary of Ingrian dialects, Inkeroismurteiden käänteissanasto edited by Raimo Jussila (1986). He uses the term donor language (Fi. lainanantajakieli) and indicates that the information concerning the donor languages is taken as such from Nirvi's dictionary (Jussila 1986: IV). Nirvi, though, usually only compares words in different varieties with the Ingrian words. An asterisk marks the words that are not entry words in IMS according to Jussila, an asterisk in parentheses marks the words that are not entry words but are not marked as such by Jussila, and an exclamation mark shows the words which are not at all compared with other Finnic words by Nirvi himself. The words are as follows: 
Ing. järkü 'bench, stool', !kalan|marja 'caviar', karjusti 'herdsman', •kuhja 'haystack; heap', *kuhje 'id.', kä̋ü 'spool', köhä 'cough', !köhähellä v., !köhähtäissä 'to cough once', !köhäht $\bar{a}$ 'to cough once', lauDa 'board, plank; table', !lauta|hurst'i 'tablecloth', luikkoi 'swan (Cygnus)', •lännikkö 'wooden tub', !mäyGü 'display (of birds)', mäyGüDellä 'to learn to play sth', (*)mäyGüttä 'id.', -piho 'hallow of the hand, palm; a handful of linen', !(*)ristetti 'godfather', !*rist|ätti 'id.', rūoja 'dirt, rubbish', !(*)rüojahussa 'to get dirty', !rūojakas 'dirty', (*)ru ojjakkaine 'id.', !r $r^{u} \overline{o j a t a}$ 'to make dirty', !(*)ru ojattua 'to get dirty', r rōma 'trace (in harness)', rüppü 'lap, hem', sōja 'warm', !s $s^{u} \overline{o j a} \mid$ paita 'sweater, cardigan', $!\left(^{*}\right) s^{u} \overline{o j a} \mid$ sāppād 'shoes made of felt', !(*)s ${ }^{u} \overline{o j a} \mid$ sä 'warm weather in the wintertime', ! $s^{u} \overline{o j e n n e l l a}$ 'to warm yourself up', ! $s^{u} \overline{o j e n t a}$ 'to warm up', !säri|marja 'calf', •vāttia 'to look', väljä̈z 'outside', *väljä 'away', !äDiDöin 'fatherless', ätti 'father' (all < Est./Vo.; words with a bullet in front of them are primarily borrowed from Vote).

Ing. •ahteri 'stern (of a ship)', •*ahter|speili 'id.', •*ahteri|seili 'spanker, driver (the last sail of a ship)', •*ahteri|tammes 'stern $\log$ of a ship', •*ahteri|toppi 'top stern sail', •aykkuri 'anchor', - hālaDa 'to hoist sails, to draw on land (a ship, for example); to gather sth', •jahti 'ship or boat with one mast', kurssi 'direction; course' (Nirvi: < Fi., comp. Rus.), !leDiDä v. 'of plaiting warp', !leDittä 'to plait', letti 'plait made when warping fabric; plait', !letti|maDo " "plait of worms", a lot of worms together', !lettiä 'to plait', lìkki 'reinforcement of the outer edge of a sail', mamma 'mother', nōtti 'note', parkki 'willow bark', !parkkia 'to bark hide into leather', -pirkkeli 'a piece of wood with which the sail of a ship is tautened', posti 'post office; postman', puttēli 'bottle', !puteli|kanta s., rākki 'carcase, scrap, wreck', !rākkia 'to spoil by hitting; to maltreat', rāmi 'frame', •rīkki 'state', •rigki 'circle', -vint(t)eli 'gimlet, auger', •*vintelin 'id.', !•(*)vokka|seili 'foresail', ülöz 'up', *ülesse 'id.', *ülez 'id.' (all < Fi./Est.; words with a bullet in front of them are primarily borrowed from Estonian. The words rāmi and vokkaseili may also have been borrowed from Russian.) 


\subsubsection{Research on Estonian}

In her doctoral dissertation, Tiina Söderman (1996) studied 698 words found in at least three of the parishes of the Estonian northeastern coastal area not attested anywhere else in the Estonian language area. The data source is VMS. The exact subdialects in the study are the Northeastern Coastal dialects of Jõelähtme, Kuusalu, Haljala, Viru-Nigula, Lüganuse, Jõhvi, Iisaku, and Vaivara, complemented with the Central dialect of Jõelähtme, Kuusalu, Haljala, Iisaku, Kadrina, and Rakvere (see Map 5). Söderman (1996: 39, 157) gives one Estonian (NE) dialect word, ilama, with the donor language being either Ingrian or Vote. According to her (ibid.), in the eastern part of the area and especially in Vaivara, it is not always clear if the Estonian dialect words in question are borrowed from Finnish or Ingrian/Vote. She gives eleven examples of these words:

Est. (NE) akkun 'window', kaarn(a) 'pine bark; float of a net; wart', karsin 'pen for pigs and calves', kiista 'race', kimbur 'bitter, sour (e.g., milk)', kokk(a) 'hook, fork', mutkas 'playful, trick', parv 'choir loft', peugal 'thumb', pulika(s) 'wooden plug, little stick', raadu raado 'miserable; thin, bad creature, loathsome' (all $<$ Fi./Ing./Vo.).

In fact, in the word articles, Söderman (op. cit., s.v.) has considered all eleven of these words to be likely Finnish loanwords. All of the examples are not actually even attested in Vote and Söderman also does not take the extent of the distribution in Ingrian and Vote into consideration. However, in my opinion, some of the distributions are found over such a limited range that there is no question about the donor variety.

Kaja Toikka (2003) studied the vocabulary of the eastern part of the northeastern coastal area of Estonia in her master's thesis. Her data consist of 432 dialect words from VMS all attested in two of the following parishes, Viru-Nigula, Lüganuse, Jõhvi, Iisaku, and Vaivara (see Map 5), but nowhere else in the Estonian language area. Toikka (2003: 21-113) gives approximately 40 Estonian Northeastern Coastal dialect words in two parishes with a distribution in Vote and Ingrian as well. However, for example, for rengi $\sim$ trengi $\sim$ renki she gives no attestation in Ingrian, although this word is widely known in 
Ingrian (IMS 473, 597). For most words, she assumes they are shared among the different Finnic languages and descend from the common protolanguage. Additionally, there are Russian loans found in all of these varieties; however, these are not discussed in this article. The following words were analysed by Toikka:

Est. (NE) ahas 'narrow, tight', ?alenema 'to go down', aruma 'to rake', arvutus 'riddle', eru 'apart', iha 'sleeve' (<Vo.), ?ilgu 'totally', issunda(i)ne 'young plant', jurmakas 'unable to comprehend', ?kangane 'of linen', kardin 'pen for animals', karisema 'to drop, to fall', kehnu 'shabby, poor', kuja 'street', kukk 'flower', ?kutkuma 'tingle', lamuma 'to lie (on sth)', lantu 'rutabaga, swede (Brassica napus)', ?lebemed 'cardfuls (of wool)', lekku 'open fire', ?levitus 'layer of straw', liemina 'lambwool', liugupäev 'Shrove Tuesday', ?liugutama 'to slide down a hill', ?moningu(i)ne 'some kind of, to some (extent)', ?muhverdama 'to devour', mummoka(i)ne 'bug', mögetama 'to bleat', panetamma 'to slander', peli 'game', ?pigar 'snaps', ?pumbukene 'water lily', raagus 'raw, rare', ?raaked 'remnant', roju 'storm', siint 'from here', takjaine takkiaine 'burdock', tohestama 'to open (an abscess)', tolked 'tuft, something hanging', vüht(i) 'skein', ümmargaine ümmärgäine 'round'.

In comparison, the master's thesis of the present author (Björklöf 2012) deals with the vocabulary in the western subgroup of the Estonian Northeastern Coastal dialects. The data consist of words attested in at least two of the following parishes: Jõelähtme, Kuusalu, and Haljala (see Map 5) but nowhere else in the Estonian language area. The data source is VMS. These three studies of Estonian dialect vocabulary show clearly that influence of Vote and Ingrian is apparent in the eastern part of the northeastern coastal area, but at the same time, no influence of Vote or Ingrian exists in the western area. (See also Pajusalu et al. 2009: 154.)

In his articles, Paul Ariste (1962: 16-17; 1977: 9; 1981: 57) points out seven loans in the Estonian Vaivara dialect (see Map 5) spoken on Estonia's eastern border. These words may have been borrowed from any of the other Finnic languages of Ingria:

Est. (Vai) iha 'sleeve', kukkane 'flower', nauhha 'ribbon', paita 'shirt', papu 'bean', puikko 'pin', süksü 'autumn' (all < Fi./Ing./Vo). 
Ariste notes that there are several loans from Finnish, Ingrian, and Vote in the Estonian dialect of Vaivara. However, in his three different works from three different decades, the only examples he provides of the numerous loanwords he had mentioned are these seven words. ${ }^{11}$ This subject matter will be examined more carefully in the future. Nevertheless, having examined a larger lexical corpus, it can be reported that there certainly is a large amount of words borrowed from Finnish as well as from either Finnish or Ingrian in the Estonian dialect in Vaivara.

\subsection{Analysed examples of mutual borrowing}

In this article, five of the words mentioned above are discussed: trehvata from Lauerma (1993), hulkkua and polle from VKJo, ilama from Söderman (1996), and roju (s.v. raju in this article) from Toikka (2003). The other words discussed in the following sections, heikko, kiuru, raju, and höyry, are words I have otherwise come across when conducting my research. These words are chosen because they are methodologically illustrative examples of mutual borrowing. Some of the etymologies are totally new. The rest of the words given above will be analysed in my forthcoming doctoral dissertation.

In the next sections, the words are presented according to the following principles. The variant of the words chosen for the numbered headings corresponds to their appearance in the donor variety; only one variant is given. For example, the first heading is "EstN, EstS trehvama 'to meet accidentally; to happen' > Vo., Ing.", because this Estonian word has been borrowed into Vote and Ingrian. The words are discussed in an order of increasing complexity. For example, the first Estonian loanword I discuss is trehvama, because its etymology is the most straightforward, I continue with põll, and conclude the section with hulkuma, because its relationship with other Finnic varieties is more complicated. In order to make the text easier to follow, variants drawn from different Finnic varieties as well as comments on their areal distributions are given at the beginning of each word section. The order of presenting the words is Vote, Ingrian, Estonian,

11. Constructing hypotheses on language contacts in this way but not providing substantial evidence for them is, in fact, common to Ariste (see Junttila 2015: 26). 
and Finnish, followed by possible variants in other Finnic languages (Karelian, Lude, Veps, and Livonian). When quoting dictionaries, the explanations of meanings given in Finnish and Estonian have been translated into English; however, some German explanations have been left untranslated in the text. Some Jõgõperä and Kukkuzi variants of Vote are given with different orthographies due to different practices in dictionaries. The dictionary sources are marked when giving the words for the first time (see the list of sources of data at the end of the article; all of them have been searched for these words).

\subsubsection{Estonian loanwords in Vote and Ingrian}

Estonian loans in both Vote and Ingrian can be relatively easy to identify because they usually are words not attested in the northern Finnic varieties, in (Ingrian) Finnish, for example, and in Ingrian, of course. The areal distributions in the investigated varieties give us clear evidence for the direction of diffusion - especially when it comes to Vote, another southern Finnic variety.

1) EstN, EstS trehvama 'to meet accidentally; to happen' $>$ Vo., Ing.

Vo. trehvata $\mathrm{Li} \mathrm{Ra}(\mathrm{Lu}) \sim$ trehvõt J-Tsv, pr. trehvaan Li Ra J; trehvaa (P), pr. trehvaab $\mathrm{Ku}$ 'to happen', trehvama, trehvet J-Tsv 'id.', trehvāB $\mathrm{Ku}$ 'id.' (VK; VKJo; VKKu)

Ing. trehvaDa Me 'to happen; to meet (sth)' (IMS)

EstN, EstS trehvama $\sim($ t)rähvama $\sim$ rehvama widespread 'to meet someone (by accident); to happen; to meet' (VMS) (< Germ. treffen)

Fi. treffata LounSm EPohjanm, areally Häme Kpohjanm PSm trehvata areally Häme dialects rehvata areally Häme and Savo dialects; Peräp 'to meet' < Swe. träffa 'to meet; to happen' (SSA)

The verb 'to meet accidentally; to happen' is attested in three dialects of Vote and one dialect of Ingrian, in fact only in a single Ingrian parish: Vo. trehvata $\sim$ trehvõt $\sim$ trehvaa, pr. trehvaab 'to happen', Ing. trehvaDa 'to happen; to meet (sth)'. In Estonian, the German loanverb (treffen $>$ ) Est. trehvama $\sim($ t)rähvama $\sim$ rehvama 'to meet someone (by accident); to happen; to meet' is widespread, which is a clear 
indicator the word is an Estonian loan in both Vote and Ingrian. In Vote, the word is attested in the Vaipooli area and Kukkuzi, which are the typical areas most likely to have taken loanwords. Unfortunately, only a few words are this clear and straightforward. Ariste (1987: $23,29)$ has indicated that his Vote-speaking language consultants use words of Estonian origin when talking about their connections with Estonians, the word in question being one of the examples; Lauerma (1993: 178) has also compared these three words. The second Finnish etymological dictionary, Suomen sanojen alkuperä (SSA), shares my view on the Estonian origin of this word in Vote and Ingrian (however, SSA presents some peculiar forms of the words in question that are not found in other dictionaries: Vo. trehveta, Ing. trehvata ${ }^{12}$; the Vote form is also given in SKES). In the first Finnish etymological dictionary, Suomen kielen etymologinen sanakirja (SKES), it was suggested that the word in Vote and the word trehvata used in so-called Estonian Ingria ("Viron Ink.") - the area ceded to Estonia in 1920 - have been borrowed from Estonian, German being the donor language of the Estonian word. In SSA, the term "Viron Ink." used in SKES has been interpreted to stand for a dialect area of Finnish - which would mean approximately the dialects of Kallivere, Kosemkina, and Narvusi although the term is not explained in SKES (SSA uses "InkVi" for Estonian Ingria). In any case, nowadays this word does not seem to be known in the Finnish dialect of Ingria; at least none of Muslimov's language consultants know this word (Mehmet Muslimov, p.c. 16 \& 17 October 2015). In (mainland) Finnish, the same word has been borrowed separately from Swedish: Fi. treffata $\sim$ trehvata $\sim$ rehvata 'to meet' < Swe. träffa 'to meet; to happen' (SSA). Also according to the Estonian etymological dictionary EES, Vo. trehvata $\sim$ trehvaa 'to happen' and Ing. trehvada 'to happen' are borrowed from Estonian.

12. The source for the Ingrian word is Sovijärvi (1944: 39), who actually gives the form trehvaDa. 
2) EstN, EstS põll 'apron'

$>$ Vo., Ing., Fi.

Vo. polle Lu Li Ra J-Tsv $\sim$ pollõ Lu J (R-Eur), g. pollee Lu Ra J $\sim$ pollõo $\mathrm{R} \mathrm{Lu}$ 'apron' (VK; VKJo)

Ing. polle Re Sa Vi (Paulaharju) Hev Kur Uus Vää Ro polli $\mathrm{Hev}$ 'apron' (IMS; IKHe)

EstN, EstS põll poll põlles (gen. põlle $\sim$ polle) widespread 'apron' (VMS); in the Northeastern Coastal dialects poll Jõe Kuu ${ }^{13}$, polle VNg Vai, põll Lüg Jõh (EMSkk)

Fi. polle Kanteletar, Gulf of Finland islands, Ink 'apron' (SSA) (at least Tyt Lava Tyrö Mol Nov Kap Kat Kose ${ }^{14}$ )

The same word for 'apron' is attested in four Finnic varieties. In Vote, polle pollõ 'apron' is attested only in the Vaipooli area and in Ingrian, polle $\sim$ polli 'id.' in three dialect areas out of four. In Estonian, the word põll $\sim$ poll $\sim$ põlles (gen. põlle $\sim$ polle) 'id.' is widespread and it has several phonological variants. In Finnish, polle 'id.' is attested only in Ingrian Finnish dialects in parishes where contacts with speakers of Estonian and Ingrian have emerged. Consequently, it is an Estonian loanword in Finnish, in Vote, and most likely in Ingrian as well, because the southern Finnic variety Estonian and the northern Finnic variety Ingrian do not share words exclusive to them. The phonetic systems of Ingrian and Finnish lack the midvowel /o/ which has been substituted in these Estonian loans with the nearest vowel /o/. The absence of initial syllable /õ/ in the variants polle $\sim$ pollõ in Vote refers to a loan origin: in this case the word might have been borrowed via speakers of Ingrian and Finnish if not from the Estonian variants poll polle. The non-initial syllable /õ/ in the variant pollõ in Vote, on the other hand, is typical for Vote: it is an accommodation to the variety's own structure, also known as etymological nativisation (on this phenomenon, see A. Aikio 2007). Lauerma (1993: 186) compares the word in Vote only with Ingrian and with the Finnish of Kosemkina

13. According to Posti (1970: 470), the variant poll would be known in Haljala, but in the Word register of the Dictionary of Estonian dialects (EMSkk) there is no such slip. 14. According to Muslimov (2015), Fi. polle is known in the Finnish dialect of Moloskovitsa and also in the Finnish dialect of Tyrö, Novasolkka, Kaprio, and Kattila (Mehmet Muslimov, p.c. 16 October 2015). I have found its use noted in different sources from Tytärsaari, Lavansaari, and Kosemkina. 
even though Äimä (1901: 33) and Ojansuu (1916: 173) had already written that Fi. polle in Tytärsaari is an Estonian loan. In VKJo there are doubts about the origin of the word and Vo. polle in Jõgõperä has been considered an uncertain Ingrian or Estonian loanword, which is indicated with a question mark. In IMS, Ing. polle is compared only with the Estonian word põll. SSA and EES ${ }^{15}$ consider the direction of borrowing to be Fi., Ing., Vo. ${ }^{16}<$ Est., quite like I do, while Posti (1970) considered it to be Ing., Vo. < Est. SKES states that the Estonian dialect word in Vaivara would be polle and in Haljala poll, which is likely because the dialects in question do not have the midvowel /ô/. According to the Word register of the Dictionary of Estonian dialects (EMSkk), the variant poll is attested in Jõelähtme and Kuusalu, polle in Viru-Nigula and Vaivara (see also footnote 13). The background of the Estonian word has been analysed in more detail in articles by Posti (1970) and Oja (2005).

\section{3) EstN, EstS hulkuma 'to wander around'} $>$ Vo., Ing., Fi.

Vo. ulkkua Kett. M J (K-Ahl. R-Lön. P) hulkkua Lu Li J (Ku) xulkkua $\mathrm{J} \sim$ hulkkuaG I 'to wander around; to walk', huлkkuma, hилkkиа J-Tsv 'id.', hилkkиа хилkkиа Ku 'id.', hилkkиаG Ma 'id.' (VK; VKJo; VKKu; VKMa)

Ing. hulkkua Me Sa L-Suu Ro 'to wander around' (IMS)

EstN hulkuma $\sim$ (h)ulkma $\sim$ ulkama widespread 'to wander around' (VMS)

EstS hulkuma $\sim$ hulkma $\sim$ ulkima 'to wander around' (VMS)

Fi. hulkkua Lönnrot $18744^{17}$; Ink (only Nar ${ }^{18}$ Kall), hulkutella Eastern dialects, Kall in INK, hulkkia Uusikirkko Vpl., hulkehtia Ilomantsi 'to wander around / umherschlendern' (SSA; SMS)

Li. *ulk pr. $u \bar{l} \grave{k} k \hat{b} B \mathrm{SjW}$ 'herumziehen, herumstreichen / to wander around' (LW)

15. According to EES, even the Estonian Swedish word päll 'apron' is a loanword from Estonian.

16. SSA records the word in Vote only from Jõgõperä (Tsvetkov).

17. A name (and a year) given in SSA stands for the first occurrence of the word in written Finnish.

18. According to Muslimov, Fi. hulkkua is known in the Finnish dialect of Narvusi and Kosemkina (Mehmet Muslimov, p.c. 16 October 2015). 
The verb 'to wander around' is attested in all southern Finnic varieties, namely Vote, North Estonian, South Estonian, and Livonian. It is found in three dialect areas in Vote: ulkkua $\sim$ hulkkua $\sim$ xulkkua $\sim$ huлkkuaG 'to wander around; to walk', in Estonian hulkuma $\sim$ (h)ulkma $\sim$ ulki$m a \sim$ ulkama is widespread (see above for the division of the North and South Estonian variants), and in Livonian *ulk pr. $u \overline{l k k} \hat{\partial} B$ 'herumziehen, herumstreichen / to wander around' was originally given in the Livischdeutsches und deutsch-livisches Wörterbuch ('Livonian-German and German-Livonian dictionary') by Sjögren and Wiedemann from 1861. The southern distribution, as there is a cognate also in Livonian, suggests this might be an inherited word also in Vote, as does its presence in two eastern Vote villages, Itšäpäivä and Mahu. However, taking a closer look at the Livonian word with only one attestation raises the question of a more probable Estonian loan origin and Kettunen in LW in fact has compared the word with Estonian hulkuda. In addition, the word-initial $/ \mathrm{h} /$ has disappeared in the development of Vote and therefore is a sign of a loan origin. The variants lacking $/ \mathrm{h} /$ appear only in older data, which are not the most accurate in their marking of the linguistic material and therefore might not be the most reliable. In these cases, etymological nativisation is also possible (see A. Aikio 2007). In Ingrian and Finnish, the word is a loan from Estonian: Ing. hulkkua 'to wander around' in two dialect areas and Fi. hulkkua 'to wander around / umherschlendern' in two parishes, although the Ingrian word might also have been mediated via Vote and the Finnish word via Ingrian or Vote. In Finnish, the word is attested only in Ingrian Finnish dialects in western Ingria, the contact area with other Finnic varieties. Laanest (1964: 31) and also Krohn (1901: 238) have considered the Ingrian word (Krohn ibid.: in western Ingria) to be a probable Estonian loanword and Savijärvi (1998: 276; repeated in Savijärvi 2001: 163) has proposed that the word in the Finnish dialect in western Ingria is "an item from Ingrian, Votian, or Estonian". In VKJo Vo. huлkkua 'to wander around' is considered either as an Ingrian or Estonian loan, and in IMS Ing. hulkkua is compared with Est. hulkuda. Ahlqvist (1856: 157) considers the words in Vote and Estonian to be equivalents and strangely enough, SSA considers all the words to be equivalents. Ojansuu (1916: 138-139) considered this word in Finnish - with the meaning 'to wander around; Fi. kuljeksia' - to be a literary loan from Estonian (borrowed in the $20^{\text {th }}$ century by Lauri 
Kettunen) and that its "original" meaning in Finnish would be "hölskyä", 'to swash, slosh, slop about'. However, it is more likely that the word is a homonym. EES ${ }^{19}$ follows SSA and considers the stem to be a Finnic stem and does not indicate any mutual borrowing.

\subsubsection{Finnish loanwords in Vote, Ingrian, and Estonian}

Etymologising loanwords in Vote, Ingrian, and Estonian with Finnish as the possible donor variety can be difficult due to lack of materials. Even though the Finnish dialect collection in the Archive of the Dictionary of Finnish dialects (SMSA) is considerable, the materials on Ingrian Finnish dialects are unfortunately inadequate ${ }^{20}$ (see Elomaa 1989: footnote 2, 37-39; Lauerma 1993: 161). However, when a word is widespread in mainland Finnish, there is little reason to assume it would not be known in the Ingrian Finnish dialects. In such cases it is reasonably safe to suppose the word in question was part of the Ingrian Finnish vocabulary as well. As for words with a limited distribution in Finnish, the lack of comparative data makes it impossible to elaborate on their etymology.

Fi. heikko 'weak'

$>$ Vo., Ing., EstN (A TOTALLY NEW ETYMOLOGY)

Vo. heikko K-Al. M-Set. J-Tsv. Ku eikko K-Ahl., g. heikoo J 'weak; thin; poor' (VK; VKJo; VKKu)

Ing. heikko Me Re Sa Sä 'weak' (IMS)

EstN (h)eik Kuu 'weak' eiko Vai 'fussy, mercurial' (EMS)

Fi. heikko Agricola; widespread heiko Satak Häme EPohjanm Peräp Länsip heikeä LönnrotLis 1886; dial. 'weak', heiketä, heikentyä 'to weaken' (SSA), widespread (SMS)

Ka. heikko rare 'weak, poor' (KKS; SSA)

Ve. heikembāne southern dialects 'weaker' (VVS; SVJa; SSA)

19. According to EES, even the Estonian Swedish word holka 'to wander around' is a loanword from Estonian.

20. According to Jussila (ed., 1991), in SMSA, Archive of the Dictionary of Finnish dialects, the number of word slips from western Ingria are as follows: Moloskovitsa 469, Novasolkka 0, Hevaa 0, Kaprio 0 (however, there is one example from Kaprio in SMS, s.v. järven|emä), Soikkola 0, Kattila 38, Narvusi 64, Kosemkina 0, Kallivere 35573. 
The word for 'weak' is attested in three dialect areas in Vote and in one dialect area in Ingrian and Estonian: Vo. heikko eikko 'weak; thin; poor' in Kattila (the materials are old), the Vaipooli area, and Kukkuzi; Ing. heikko 'weak' in Soikkola, Est. (h)eik eiko 'weak; fussy, mercurial' in the Northeastern Coastal dialects. The limited distributions refer to a loan origin from Finnish, where the word heikko is widespread and has phonological variants as well as verbal derivations (heiko,

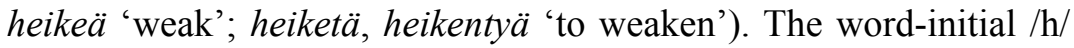
in Vote is an indication of a loan origin because historically it has disappeared in Vote and, additionally, at least eleven other words with the meaning 'weak' have been attested in Vote according to VK. The Estonian dialect words have in fact been borrowed from two different directions: Kuusalu, a parish located east of Tallinn, most likely received the word across the Gulf of Finland from either the coastal area of Kymenlaakso or the Karelian Isthmus (about the borrowing areas, see Björklöf 2012; 2017; 2018), while Vaivara on Estonia's eastern border borrowed it from Ingrian Finnish. The Karelian rare heikko 'weak, poor' in two dialect areas out of three is also a Finnish loan according to SSA. In the southern dialects of Veps only the comparative heikembāne 'weaker' is attested, which seems peculiar, but there actually are strange derivations in Veps without an attested stem, -Ane in fact being one of the derivational types. Lauerma (1993: 165), oddly enough, compares the word in Vote only with Ingrian but not with Estonian or even with Finnish. Ahlqvist (1856: 123), one of the first linguists studying Vote, considered the words in Finnish and Vote equivalents, which is not the case, because in Vote, there is no word-initial $/ \mathrm{h} /$ and words with $/ \mathrm{h} /$ in this position are always borrowings or at least are the result of later influence from other languages. Surprisingly, SSA also does not take borrowing into consideration and instead treats the words as cognates. 


\section{5) Fi. kiuru 'Eurasian skylark, Alauda arvensis' $>$ Vo., Ing. (A NEW ETYMOLOGY), EstN}

Vo. kiuru Kett. K P M Kõ S Lu Ra J I $\sim$ k'iuru J-Tsv. $\sim$ tšiuru K-Ahl. Li $(\mathrm{M}) \sim$ Kïypo Tum. 'Eurasian skylark', kiuru 'id.' J-Tsv Ku, kiurukkõin JTsv. J dem. 'id.' (kiurukkęin J-Tsv), kiurulintu M 'id'; kiuruttaa JTsv. J 'to trill, to warble', kiurutôlla JTsv. J freq. $\leftarrow$ kiuruttaa; kiuruttema, kiurutta, kiuruttęma, kiurutę̄ J-Tsv 'to trill, to warble' (VK; VKJo; VKKu)

Ing. kiuru Re Sa Ro 'Eurasian skylark' (IMS)

EstN kiur Hlj VNg Lüg Jõh IisR Vai Iis Kod kiuro Vai 'Eurasian skylark'; kiurama Hlj, tsiuruma IisR 'to trill, to warble' (VMS; EMS)

Fi. kiuru Juslenius 1745; mostly E dial. ${ }^{21}$ 'Eurasian skylark', kiur(u)inen, kiuri SE dial. 'Eurasian skylark' (SSA); probably partially literary; vernacular especially in KAR INK (SMS)

Ka. kiuru $\sim$ k'iuru widespread, kiurinki Paatene 'Eurasian skylark'; kiuruta Paatene 'to trill, to warble' (KKS; SSA)

Lu. kiur $\mathrm{Sn} \sim$ kiuroi B $\sim$ k'iuru Lm $\sim$ kiuruine $\mathrm{B}$ 'Eurasian skylark'; kiuruta Sn $\sim$ kiuruttada B 'to sing like an E. skylark' (LS; SSA)

The name of the bird 'Eurasian skylark' in Vote, Ingrian, and Estonian is most likely a Finnish loan: Vo. kiuru $\sim$ k'iuru $\sim$ tšiuru $\sim$ Kïypo 'Eurasian skylark' (attested also in Eastern Vote), Ing. kiuru 'id.' (in two dialect areas, Soikkola and Rosona ${ }^{22}$ ), EstN kiur $\sim$ kiuro (NE, E dial.) 'id.' < Fi. kiuru (Jusl 1745; mostly E dial.) 'id.', kiur(u)inen, kiuri (SE dial.) 'id.'. In Karelian, kiuru k'iuru is widespread and in Lude, kiur $\sim$ kiuroi $\sim$ k'iuru $\sim$ kiuruine are also attested. In Finnish, this word has been regarded either as onomatopoeic (SSA) or a potential Baltic loanword (Kalima 1936; SKES; SSA). In studies on Finnish bird names, Marttila (2010: 196) follows SSA and classifies the word as onomatopoeic or a loan, but Salminen (2010: 352) categorises the Finnish word as an onomatopoeic word. The most recent etymological study (Junttila 2015: 102, 108) regards the possible Baltic etymology given

21. Also in the Finnish dialect of central and northern Ingria (Rääp Sku Kup) (Mehmet Muslimov, p.c. 16 October 2015).

22. Rosonanjoki (Rosona River) dialect area according to J. Mägiste (1925): Ingrian dialects spoken in so-called Estonian Ingria. 
in SKES as controversial due to the way in which the etymology has been received by the research community. The derivation of the word is defined to be irregular and the word is categorised as part of a group of words listed as descriptive, contaminations, or onomatopoeic (ibid.).

The words could be cognates in all of the eastern Finnic varieties (Eastern Finnish dialects, Ingrian, Karelian, Lude). However, the limited distribution in Ingrian suggests a Finnish loan origin. The sound change $* k>t \check{s}$ in front of front vowels in itself is the most characteristic feature in Vote, but in the variant tšiuru in Vote it probably is only a Votism in a loanword, as Lauerma (1993: 167) has also suggested; in modern terms it has to be classified as a result of etymological nativisation (see A. Aikio 2007). Suhonen (1986: 152) gives the words in Vote as an example of loans with either Ingrian or Ingrian Finnish origin. Kettunen (1930: 17 [1915: 16]) considered the path of borrowing to be Vo. kiuru $<\mathrm{Fi}^{23}$ and SSA similarly lists it as Vo. tšiuru $<$ Fi. However, the latter is the only borrowing of this word between the Finnic varieties given by SSA. The word in Vote was also mentioned by Setälä (1964) as a cognate of the Finnish word. Mägiste (1927) considered the word to be a loan from Vote into Estonian, and the variant siuru ( $<$ Vo. tšiuru) in old folk songs in fact might be one, as Saareste (1952: 62) also writes. Laakso regards Vo. kiuru (in Ku Ma, Setälä's materials, and Kettunen 1915) as a loan from either Finnish, Ingrian, or Estonian in the Reverse Vocabulary of Vote (Laakso ed. 1989). In the reverse vocabulary of the Vocabulary of the Joenperä (Jõgõperä) dialect of Vote (VKJo, Laakso ed. 1995), the nouns Vo. kiuru, kiurukkein in the Jõgõperä dialect are considered loans from Ingrian and the verbs Vo. kiurutta, kiuruteлл in Jõgõperä are regarded as having been borrowed from either Ingrian, Finnish, or Estonian, although there are no such Ingrian or Finnish verbs in the dictionaries. In Vote, Estonian, and also Lude, verbs used to describe the singing of this bird have even been attested in a couple of areas in each variety: Lu. kiuruta, kiuruttada 'to sing like an E. skylark'; Vo. kiuruttaa; kiurutõlla (freq.) (JTsv. J) 'to trill, to warble'; Est. kiurama (Hlj), tsiuruma (IisR) 'to trill, to warble'.

23. In fact, Kettunen (1930: 17 [1915: 16]) writes: "Words like these [with $k$ before a front vowel] are borrowings from other Finnish dialects of Ingria - -" (my translation and italicisation): in the context of the time of writing in question (and considering the pronoun other), this might be interpreted to mean other Finnic languages or varieties of the area. In SSA it simply has been interpreted to mean dialects of Finnish. 
The phonetic form of the latter Estonian variant in Iisaku, located west of the easternmost Estonian parish Vaivara, might have some influence from Vote. Ariste (1956: 15), on the other hand, has treated the Estonian Northeastern Coastal kiur and the Finnish kiuru as cognates and Mäger (1967: 128) has considered the Estonian word an onomatopoeic word.

\section{Fi. raju 'wild; severe, hard'; in compounds meaning 'storm'} $>$ Vo., Ing., EstN (A TOTALLY NEW ETYMOLOGY)

Vo. raju P 'storm', comp. raju-ilma: Раю-Илма Pal. 'storm', raju|ragõ $\mathrm{M}$ 'hailing, hailstorm', raju|vihma L 'rainstorm'. Also roju Lu Li Ra 1. Lu Li 'storm' 2. 'stormy'; rojukaz Lu Li 'stormy'. (VK)

Ing. raju adj. 'fierce' Me usually raju ilma 'bad weather' Sa. Also roju n.: roju Ro 'storm'; roju|ilma L-suu 'rainy, windy, and stormy weather'; rojugas adj. L-Suu 'r-y, w-y, and s-y (about weather)'; Sa 'quarrelling'; rojustaa v. Sa 'on a bad, r-y and s-y autumn; to quarrel'; rojuz n. Sa 'r-y, w-y, and wet autumn; bad-mannered'. (IMS)

EstN raju rajo Lüg Jõh IisR Vai Khk VJg Trm Kod Äks Lai 'storm'. Also roju 'storm' VNg Lüg. (VMS)

Fi. raju Hemminki 1605; widespread 'wild; severe, hard; (also areally dial.) large, enormous', comp. raju|ilma Finno 1583, raju|myrsky (SSA)

Ka. raju adj. 'on wind, rain: hard, heavy; on animals: fierce' (KKS; SSA)

The word for 'storm' is attested in all three analysed varieties: EstN raju rajo 'storm' in northeastern and eastern parishes; Vo. raju 'id.' in one village, compounds raju|ragõ 'hailing, hailstorm', raju|vihma 'rainstorm' both in one village; Ing. raju (adjective according to IMS) 'fierce', usually raju ilma 'bad weather' in two villages. In Finnish, the word is widespread: Fi. raju 'wild; severe, hard; (also areally dial.) large, enormous', and it is attested also in compounds raju|ilma, raju|myrsky. In Vote, Ingrian, and Estonian, raju has to be considered a Finnish loan because of its wide distribution in Finnish and limited distribution in the recipient varieties - and also due to its semantics: in Finnish, this word has more meanings, in the recipient varieties it only refers to a storm (in Ingrian, it is used only as an adjective). The Estonian attestation in the westernmost parish of Kihelkonna on the island of Saaremaa is most likely also a Finnish loanword, because this is another contact area with Finnish. In SKES, the Finnish, Karelian (in two 
dialect areas out of three), and Estonian words are considered to be equivalents, which I doubt, because an old word in North Estonian also would be found in South Estonian. SSA does not give the variants in Vote and does not take any borrowing into account, either, but considers the Finnish, Ingrian, Karelian, and Estonian variants cognates. EES simply considers the stem to be a Finnic stem, while the distributions are not taken into account at all. A word with $/ \mathrm{o} /$ in the initial syllable and a couple of derivatives of it are known as well, attested only in Vote in the Vaipooli area, in Lower Luga and Soikkola Ingrian, and in Estonian in two northeastern parishes: Vo. roju 'storm; stormy', rojukaz 'stormy'; Ing. rojuilma 'rainy, windy, and stormy weather; storm', rojugas adj. 'rainy, windy, and stormy (about weather)', rojustaa v. 'on a bad, rainy and stormy autumn', rojuz n. 'rainy, windy, and wet autumn'; EstN roju 'storm'. These could be considered phonological variants. Toikka (2003: 83) simply writes that the word roju is a shared word in Vote, Ingrian, and the Estonian Northeastern Coastal dialects.

7) Fi. höyry'steam'

$>$ Vo., Ing. (A NEW ETYMOLOGY), EstN

Vo. hö̈̈rü Lu J-Must. J-Tsv, g. hö̈̈rüü J ‘steam', höürü Ku 'steam; air’; hö̈rüüssä: hö̈rüssä Lu hö̈rüss J-Tsv 'to steam', hö̈rrīss $\ddot{A} \mathrm{Ku}$ 'to steam', hö̈r ü̈̈ J-Tsv 'to steam; to stagger, to totter (with fatigue)', höürütellä: höürütell J-Tsv 'to steam sth' (VK; VKJo; VKKu)

Ing. hö̈rü 'fog' Me 'steam' Sa; höürüssä Me L-suu 'to steam', hö̈rüttää Me 'to steam', hö̈rüdellä freq. Me 'to steam sth' (IMS)

EstN ö̈rr ö̈rü öur VNg Lüg Jõh Vai 'steam', ôur Lüg, aur widespread; ö̈rüne 'steamy' VNg Vai; ö̈rämä 'to steam' Lüg Vai, öuritamma ö̈ritämmä 'to steam sth' VNg Lüg (VMS)

Fi. höyry Juslenius 1745; widespread, except for SW dial. and LUus 'Dampf, Dunst' (SSA); höyry widespread ${ }^{24}$; höyrytä höyrätä no data from INK 'to steam', höyryttää höyryyttää sporadic 'to steam sth' (SMS)

Ka. höyry höyry 'steam, vapour, fog; dispute' (KKS; SSA)

Lu. hö̈̈r (B) Td hö̈rü B N Ph Lm 'water vapour, steam (e.g., coming from a machine, breath in cold weather)' (LS; SSA)

Ve. hö̈r 'steam' (SSA); not in VVS or SVJa

24. Also in the Finnish dialect of central and northern Ingria (Mehmet Muslimov, p.c. 16 October 2015). 
The word for 'steam' is attested in all eastern Finnic varieties. Fi. höyry is widespread, except for in the Southwestern dialects and Länsi-Uusimaa, Ingrian höürü 'fog; steam' is known in two villages, while other attested variants include Karelian höyry 'steam, vapour, fog' (in all three dialect groups; 'dispute' in one group), Lude hö̈r(ü) 'water vapour, steam', and Veps hö̈r 'steam'. This word has been borrowed into Vote as hö̈rü 'steam' in two villages in the Vaipooli area and in Kukkuzi and into Estonian as ö̈r ö̈rü öur 'steam' in a couple of northeastern parishes. I agree with SSA, which considers these both to be Finnish borrowings. However, SSA gives EstNE forms ö̈r (g. ö̈ru), ö̈ri, öürü, of which öuri is not known in VKS; none of these forms are known in Wiedemann (1893 [1869]), which usually is the source of Estonian dialect words for SSA. In VKJo, the noun Vo. hö̈̈rü in the Jõgõperä dialect is considered a loan from either Ingrian or Finnish. As the form generally used in Estonian is aur, the Estonian variant our in Lüganuse parish might be a contaminated form in a dialect area (Alutaguse) where the midvowel /õ/ is especially productive and usually replaces the vowel /o/. In Finnish, the verb höyrytä 'to steam' is widespread, höyryttää 'to steam sth' is sporadic. In Vote, a couple of verbal derivations are known in the same villages as the noun: Vo. hö̈rüssä, hö̈rüss, hö̈rüss $\ddot{A}$, hö̈rü̈̈ 'to steam', höürütell 'to steam sth'. In Estonian, adjective ö̈rüne 'steamy' and verbal derivations ö̈rämä 'to steam', ö̈ritamma ö̈ritämmä 'to steam sth' are known in a couple of the same northeastern parishes where the noun is known. In Ingrian, the distribution of a couple of verbal derivations is even more limited, one village in Lower Luga and one village in Soikkola: Ing. höürüdellä (causative, frequentative) 'to steam sth', hö̈rüssä, hö̈rüttää 'to steam'. The Ingrian word can be considered a loan because of its limited distribution.

\subsubsection{Are there Ingrian loanwords in both Vote and Estonian?}

When it comes to possible Ingrian loans in Vote and Estonian, the donor variety is difficult to define as these words are often found in Finnish as well and also due to the phonological similarities between Ingrian and Finnish. Words borrowed into both Vote and Estonian are usually known in both Ingrian and Finnish, and therefore it is typically 
impossible to tell which variety was the source of the loan. In fact, both varieties are in a position to have mediated loans in such cases. In principle, almost every Finnish loan in Vote (which is also found in Ingrian) may have been mediated via Ingrian. The Ingrian influence on Vote has been strongest in the mixed population villages in Vaipooli (e.g., Lauerma 1993: 50), where Ingrian can be considered the primary donor variety. Vote has borrowed plenty of words from Ingrian, but as of now, I have not found loans in both Vote and Estonian which I could say with certainty were borrowed from Ingrian.

\subsubsection{Are there Vote loanwords in both Ingrian and Estonian?}

Although there are some loans from Vote known in Ingrian and possibly in Estonian as well, loans from Vote found in both Ingrian and Estonian are exceedingly scarce. For comparison, Arvo Laanest (1988) has studied 490 Vote words from the materials found in the Finnic atlas ALFE, which was being compiled at the time. The main group consists of Vote-Ingrian-Finnish words. The remainder is composed of two equally-sized groups. Laanest divides the words of these groups into those found in 1) Vote and Finnish (and usually Ingrian as well) but not in Estonian and into those found in 2) Vote and Estonian but not in Finnish. For example, in the Lower Luga area, Ingrian has a Vote substrate and the local Finnish dialect has both a Vote and Ingrian substrate (Savijärvi 1998: 274; 2001: 165; Muslimov 2005; Rozhanskiy \& Markus 2014). According to Kuznetsova et al. (2015: 133), all the Finnish varieties of western Ingria, except the dialects in Kaprio and Tyrö, have substrate vocabulary from Vote.

Although there is borrowing between Ingrian and Vote, the lack of loanwords from Ingrian and Vote into each other and into Estonian might refer to the lower prestige of these two varieties compared to Estonian. In fact, words with an attestation only in Vote and Estonian might be worth examining more closely, because of the old assumption that these two varieties have had even closer contacts in the past. 


\section{8) Vo. ilata 'to clean up' \\ $>$ Ing. (A NEW ETYMOLOGY), EstN, Fi. (A NEW ETYMOLOGY)}

Vo. ilata Al Kett R U L P M Kõ Po Lu Li J (K-Ahl. Ja-Len. V Ra Ku) ilat J-Tsv $\sim$ ilataG I 'to clean up, to put away, to cleanse, to arrange; to take care of (animals)', ілата, ілат J-Tsv 'to clean up', ілатА $\mathrm{Ku}$ 'to clean up, to cleanse, to clear away' (VK; VKJo; VKKu)

Ing. ilaDa Sa L-Suu Ro 'to clean up (slightly), to repair, to cleanse' (IMS)

EstN ilama Jõh Vai ilamaie Lüg 'to clean up; to take away' (VMS; EMS)

Fi. ilata 'to clean up, to cleanse' Kall (SMS)

So far, I have managed to find only one probable borrowing from Vote into both Ingrian and Estonian: Ing. ilaDa 'to clean up (slightly), to repair, to cleanse' in two villages and Rosona, EstN ilama ilamaie 'to clean up; to take away' in a couple of northeastern parishes. In Vote, the same verb is widespread and attested also in Eastern Vote: Vo. ilata $\sim$ ilataG 'to clean up, to put away, to cleanse, to arrange; to take care of (animals)' and VK also gives many examples of its use. Söderman ${ }^{25}(1996: 39,157)$ treats the Estonian word as a loan from either Ingrian or Vote (or as derived from the Estonian word ilu 'beauty'), but an Ingrian origin is not very plausible when comparing the distributions. A particular origin for a loanword is more likely when its distribution is like that of other borrowings. Thus, we see there are many borrowings in the same direction with a similar distribution in Estonian. In Finnish, the verb ilata 'to clean up, to cleanse' is attested only in Kallivere, where it is an apparent loanword. The word could also be a substrate word in at least Ingrian and Estonian.

25. Söderman also gives a distribution in $\mathrm{VNg}$, but the word attested there is simply a homonym with the meaning 'Est. ilastama; to make slimy'. 
8. Discussion

Areal distribution is a crucial factor for the etymological research of borrowings between closely related varieties (see also Björklöf 2018). When there are few sound criteria, the importance of distribution is emphasised. There can be other problems as well: There is a somewhat limited amount of lexical material on the small Finnic variety Ingrian (and Vote), although when compared with available Livonian materials, for example, the data from Vote are substantial (on Ingrian, see, e.g., Grünthal forthcoming: p. 23 in the manuscript). Despite the size of the collection on Finnish dialects in the Archive of the Dictionary of Finnish dialects (SMSA) being impressive even on a worldwide level, the materials on Ingrian Finnish dialects are inadequate, as mentioned earlier. In western Ingria, lexical material from Ingrian Finnish dialects has been collected almost exclusively from Kallivere. This material is worth closer scrutiny, because it contains many loanwords from other Finnic varieties of that area. Collecting newer text materials has also revealed interesting facts: according to Savijärvi (1996b: 187; 1998: 276), the Finnish dialects of the Narvusi region in western Ingria seem to have a considerable amount of lexical items from Ingrian, Vote, and Estonian, and words with these forms and meanings are apparently not found in standard Finnish or the other Finnish dialects (of Ingria). It must be noted that already Merle Leppik - in her thorough survey on the development of the phonological system of the Ingrian Finnish Kurkola dialect - wrote that Vote and Ingrian played a considerable role in the development of the Finnish dialects in Kurkola and the Lower Luga area (Leppik 1975: 197). A portion of the lexical items from Ingrian and Vote in the western Ingrian Finnish dialects can probably be considered a substratum, because a portion of the Ingrian and Vote speakers there were converted to Lutheranism and were therefore Fennicised in the $17^{\text {th }}$ century (Krjukov 1993 [1987]: 22, 23; Savijärvi 1998: 274; 2001: 165).

Overall, when investigating Finnic varieties in this particular area, careful attention must be paid to the extent and location of the distribution. We cannot take a distribution in only one or two parishes and assume the word in question derives from the protolanguage (surprisingly, this has sometimes been done when preparing the SSA, for 
example, with Ing. ennustā 'to predict' which is attested in Ingrian only in the Rosona area according to IMS). One might, of course, assume that the word has not been registered anywhere else although it "in fact" has been known more widely, but such an approach is nonscientific and should be avoided.

Examining mutual borrowing in western Ingria and northeastern Estonia shows that the hallmark of Estonian loanwords in Vote and Ingrian is usually their relatively limited distribution. As for the Estonian distributions in the present study, it seems that a limited distribution in the Northeastern Coastal and Eastern dialects usually indicates that the word is borrowed from the other Finnic varieties spoken in western Ingria. Whereas, Estonian loanwords in the other Finnic varieties in western Ingria usually have a more widespread distribution in Estonian and may also be attested in South Estonian. Lembit Vaba (2014) discusses distribution as an etymological criterion using the example of Estonian, the donor languages being genetically distant languages. As his earlier research (Vaba 1977; 1997; 2015) and the work of Mari Must (2000) have shown, loanwords borrowed from the same donor language usually have a specific, limited distribution in Estonian dialects. There are also loanwords with small, punctual distributions that appear almost scattered around. The studies of Söderman (1996) and Björklöf $(2012 ; 2018)$ show the same distributional correlation in the Finnish loans in Estonian.

Finnish, the Finnic variety with the highest prestige in Ingria, has been the donor variety for a large number of borrowings: most of the loanwords in Vote, Ingrian, and Estonian are borrowed from Finnish. Loans found in both Vote and Estonian often occur not only in Ingrian but also in Finnish. Due to the phonetic similarity of these varieties, it is usually impossible to determine the donor variety. Vote loans in Ingrian and Estonian only occur sporadically and these may also result in part from a substratum.

However, at this point there exists practically no literature on the methodology for investigating mutual contacts among closely related varieties. Riionheimo (2013) discusses the use of comparison between languages (Fi. kieltenvälinen vertailu) for studying languages in contact, but she is comparing languages, which are used in profoundly different ways in education, legislation, and in relation to national 
identity. On the contrary, areal varieties are more typical in the traditional Finnic linguistic area. When it comes to the Finnic varieties in the Lower Luga area, we can even speak of mixed varieties.

Jouko Lindstedt (2000: 242) has proposed that linguistic areas, for example the Balkans but also many others, have shown that convergence may be more than borrowing, because donor and recipient languages cannot always be clearly distinguished and there is mutual reinforcement of change. This might be the case with language areas formed by genetically related and typologically close varieties as well. In the Balkans there is morphological convergence but hardly any lexical borrowing because the languages are used as an important means of (self-)identification and they are symbols of group identity (Lindstedt 2000: 239). Therefore, this sociolinguistic situation is quite the opposite of that found in western Ingria. At the same time, this counterexample sheds light on the impact of identity issues on language change: the identity of the speech community affects the borrowing processes enormously - either on a conscious or a subconscious level.

The Finnic varieties are a continuum spoken across a relatively broad area, in which Ingria forms the core area and the meeting point of closely related varieties. The internal integration of the Finnic language area has been difficult to describe, and in their traditional speaking areas, the varieties of the present-day national languages Finnish and Estonian have considerably levelled off. In my opinion, the most fruitful way of investigating the varieties of western Ingria is to treat them simultaneously and with a comparative approach. This is because the language varieties of this region have never existed in a monolingual environment. 


\section{Abbreviations}

General: adj. $=$ adjective, comp. $=$ compound, dem. $=$ diminutive, dial. $=$ dialectal $/$ dialects, freq. $=$ frequentative, g. $=$ genitive, $\mathrm{n}_{.}=$noun, pr. $=$ present tense, $\mathrm{v}$. $=$ verb.

Other languages: Ger. $=$ German, Rus. $=$ Russian, Swe. $=$ Swedish .

Finnic varieties: Est. $=$ Estonian, EstN $=$ North Estonian, EstS $=$ South Estonian, Fi. $=$ Finnish, Ing. $=$ Ingrian, Ka. $=$ Karelian, Li. $=$ Livonian, Lu. $=$ Lude, Ve. $=$ Veps, Vo. $=$ Vote.

Dialects of Vote: Western Vote: 1) Lower Luga (Vaipooli) Vote: J = Jõgõperä, $\mathrm{Li}=$ Liivtšülä, $\mathrm{Lu}=$ Luuditsa, $\mathrm{Ra}=\mathrm{Rajo}$; 2) Central (Kattila) Vote: $\mathrm{Ja}=$ Jarvikoištšülä, $\mathrm{K}=$ Kattila, $\mathrm{Ke}=$ Kerstova, $\mathrm{Ki}=$ Kikeritsa, Kõ $=$ Kõrvõttula, $\mathrm{L}=$ Lempola, $\mathrm{M}=$ Mati, $\mathrm{Mu}=$ Muukkova, $\mathrm{P}=$ Pummala, $\mathrm{Pi}=$ Pihlaala, $\mathrm{Po}=$ Pontizõõ, $\mathrm{R}=$ Rudja, $\mathrm{S}=$ Savvokkala, $\mathrm{U}=$ Undova, $\mathrm{V}=$ Velikkä. Eastern Vote: $\mathrm{I}=\mathrm{Itšäpäivä,} \mathrm{Ii} \mathrm{=} \mathrm{Iivanaisi,} \mathrm{Kl}=$ Kliimettina, $\mathrm{Ko}=$ Kozlova, $\mathrm{Ma}=\mathrm{Mahu} . \mathrm{Ku}=$ Kukkuzi (dialect area); $\mathrm{Kr}=$ Krevin (dialect area).

Dialects of Ingrian: Ala-L $=$ Lower Luga dialect area: Soi $=$ Soikkola parish / villages: Har $=$ Harkkola, $\mathrm{Kol}=$ Kolkanpää, $\mathrm{Lo}=$ Loka, $\mathrm{Me}=$ Metsäkylä, $\mathrm{Ou}=$ Oussimäki, $\mathrm{Re}=$ Repola, $\mathrm{Ru}=$ Ruutsia, $\mathrm{Sa}=$ Saarove, Sä $=$ Säätinä, Tam $=$ Tammikontu, Tar $=$ Tarinaisi, Uus $=$ Uusikylä, Vi $=$ Viistinä, Vää = Väärinoja (a Lutheran village); Kosemkina $(=$ Nar $=$ Narvusi) parish / villages: Kur = Kurkola, L-suu = Laukaansuu, Vibjä (Vipiä). Hev = Hevaa dialect area: Kap = Kaprio parish / villages: Mur $=$ Murtove, $\mathrm{Ve}=$ Vepsä. Ro $=$ Rosonanjoki (Rosona River) dialect area according to J. Mägiste; Ylä-L = Oredež dialect area.

Dialects of North Estonian appearing in this study: Northeastern Coastal dialects: Jõe = Jõelähtme, Kuu = Kuusalu, $\mathrm{Hlj}=$ Haljala, $\mathrm{VNg}$ $=$ Viru-Nigula, Lüg = Lüganuse, Jõh $=$ Jõhvi, lisR = Iisaku (Northeastern Coastal), Vai $=$ Vaivara. Eastern dialect: Iis $=$ Iisaku (Eastern), $\operatorname{Trm}=$ Torma, Kod $=$ Kodavere, $\mathrm{MMg}=$ Maarja-Magdaleena, $\mathrm{Pal}=$ Palamuse, $\mathrm{Lai}=$ Laiuse Central dialect $\mathrm{Kad}=$ Kadrina, $\mathrm{Rak}$ $=$ Rakvere, VJg $=$ Viru-Jaagupi, Äks = Äksi. Island dialect $:$ Khk $=$ Kihelkonna. $\mathrm{E}=$ Eastern dialect, $\mathrm{NE}=$ Northeastern Coastal dialects.

Dialects of South Estonian appearing in this study: Tartu dialect: $\mathrm{TMr}=$ Tartu-Maarja, KodT $=$ Kodavere $($ Tartu).

Dialects of Finnish appearing in this study: Kymi dialects: Suu = Suursaari. Southeastern dialects: South Karelian dialects of Finnish proper (Western): Tyt $=$ Tytärsaari, Lava $=$ Lavansaari, Seis $=$ Seiskari. 
Ingrian dialects of Finnish proper (Northern) ${ }^{26}$ : HaaK = Haapakangas, Rääp = Rääpyvä, Kel = Keltto; (Eastern:) Mark = Markkova, Jär $=$ Järvisaari; (Central:) Lii $=$ Liissilä, Inkere $=$ Inkere, Ven $=$ Venjoki, Tuut $=$ Tuuteri, HieM $=$ Hietamäki, Tyrö $=$ Tyrö $(w)$, Rop $=$ Ropsu $(\mathrm{c} / \mathrm{w}), \mathrm{Sku}=$ Skuoritsa, Kolp $=$ Kolppana, Spa $=$ Spankkova, Hats $=$ Hatsina, Kop $=$ Koprina, Kup $=$ Kupanitsa, Ser $=$ Serepetta $(\mathrm{c} / \mathrm{w})$; (Western:) $\mathrm{Mol}=$ Moloskovitsa, Nov $=$ Novasolkka, Hev $=[\mathrm{Hevaa}]^{27}$, Kap $=[$ Kaprio $]$, Soik $=[$ Soikkola $]$, Kat $=[$ Kattila $]$, Nar $=[$ Narvusi $]$, Kose $=[$ Kosemkina $]$, Kall $=$ Kallivere. Dialectal areas appearing in this study: KAR = Karjala 'Karelian dialects of Finnish proper', INK = Inkeri 'Ingrian dialects of Finnish proper'. Abbreviations used in SSA and appearing in this study: EPohjanm = Etelä-Pohjanmaa 'southern Ostrobothnia', Häme = Häme, KPohjanm = Keski-Pohjanmaa 'central Ostrobothnia', LounSm = Lounais-Suomi 'southwestern Finland', LUus = Länsi-Uusimaa 'western Uusimaa', Länsip = Länsipohja, Peräp $=$ Peräpohjola, PSm $=$ Pohjois-Suomi 'northern Finland', Satak = Satakunta, Savo = Savo. E = Eastern dialects, $\mathrm{SE}=$ Southeastern dialects, $\mathrm{SW}=$ Southwestern dialects.

Dialects of Lude appearing in this study: B = Bošinkylä, Lm = Lid'žmi, $\mathrm{N}=$ Nuomoil, $\mathrm{Ph}=$ Pyhäjärvi, $\mathrm{Sn}=$ Sununsuu, $\mathrm{Td}=$ Tiudia.

Collectors of the Vote materials appearing in this study: $-\mathrm{Ahl}$. = A. Ahlqvist, - Al. $=$ V. Alava, - Eur. $=$ D. E. D. Europaeus, Kett. $=$ L. Kettunen, - Len $=$ Ja. Ja. Lensu, - Lön. $=$ E. Lönnrot, - Must. $=$ O. A. F. Mustonen, Pal. $=$ P. S. Pallas, - Se. $=$ E. N. Setälä, - Tsv. $=$ D. Tsvetkov, Tum. $=$ F. Tumanski (abbreviations are usually given with an abbreviation of a village, e.g. "K-Ahl” 'Ahqvist from Kukkuzi village').

In sources of data and references: $\mathrm{EKI}=$ Eesti Keele Instituut [Institute of the Estonian Language]; KKTK = Kotimaisten kielten tutkimuskeskus [Institute for the Languages of Finland]; KKTKJ = Kotimaisten kielten tutkimuskeskuksen julkaisuja [Publications of the Institute for the Languages of Finland]; LSFU = Lexica Societatis Fenno-Ugricae; MSFOu = Memoires de la Société Finno-Ougrienne; p.c. $=$ personal communication; SKS $=$ Suomalaisen Kirjallisuuden Seura [Finnish Literature Society]; SKST $=$ Suomalaisen Kirjallisuuden Seuran toimituksia [Publications of the Finnish Literature Society]; SUS = Suomalais-Ugrilainen Seura [Finno-Ugrian Society].

26. The Ingrian Finnish dialects are divided according to Muslimov (2009), followed by Kuznetsova et al. (2015: 132-133).

27. The parishes in [square brackets] are parishes where Finnish was not the main Finnic language. 
Sources of data

EMS = Eesti murrete sõnaraamat [Dictionary of Estonian dialects] I-VI ( $a-$ osatama). 1994-2019. Tallinn: EKI. Available at: 〈http://www.eki.ee/ dict/ems/s. Installments 1-30 in PDF format available at: http://www. eki.ee/dict/ems/pdf.html>

EMSkk $=$ Eesti murdesõnavara koondkartoteek [Word register of the Dictionary of Estonian dialects]. Archive of Estonian Dialects and FinnoUgric Languages (AEDFUL) at the Institute of the Estonian Language. Tallinn: Eesti Keele Instituut. (See (in Estonian and English): 〈http:// emsuka.eki.ee/s)

IKHe = Laanest, Arvo 1997: Isuri keele Hevaha murde sõnastik [Vocabulary of the Ingrian Hevaa dialect]. Tallinn: EKI.

IMS = Nirvi, Ruben E[rik] 1971: Inkeroismurteiden sanakirja [Dictionary of Ingrian dialects]. LSFU XVIII. Helsinki: SUS.

Jussila, Raimo (ed.) 1986: Inkeroismurteiden käänteissanasto [Reverse vocabulary of Ingrian dialects]. R. E. Nirvin Inkeroismurteiden sanakirjan aineistosta toim. R. Jussila. LSFU XVIII:2, KKTKJ 41. Helsinki: SUS \& KKTK.

KKS $=$ Karjalan kielen sanakirja [Dictionary of Karelian] 1-6. 1968-2005.

Ed. Pertti Virtaranta (1-3), Raija Koponen (4-6). LSFU XVI, 3-6 also KKTKJ 25. Helsinki: SUS \& KKTK.

$\mathrm{KKSV}=$ Karjalan kielen verkkosanakirja [Online dictionary of Karelian]. Ed.

Marja Torikka, editor in chief from 8 September 2010 Leena Joki. Internet application Jari Vihtari. Kotimaisten kielten tutkimuskeskuksen verkkojulkaisuja 18. Helsinki: KKTK. Published 15 October 2009, updated 22 February 2019 [Accessed February 2019]. 〈http://kaino.kotus.fi/kks〉

Laakso, Johanna (ed.) 1989: Vatjan käänteissanasto [Reverse vocabulary of Vote]. LSFU XXII, KKTKJ 49. Helsinki: SUS \& KKTK.

LS = Lyydiläismurteiden sanakirja [Dictionary of Ludic dialects]. 1944. Ed. Juho Kujola. LSFU IX. Helsinki: SUS.

LW = Kettunen, Lauri 1938: Livisches Wörterbuch. LSFU V. Helsinki: SUS. SMS $=$ Suomen murteiden sanakirja [Dictionary of Finnish dialects] 1-8 (a-kurvottaa). 1985-2008. KKTKJ 36. Helsinki: Kotimaisten kielten tutkimuskeskus.

SMS = Suomen murteiden sanakirja [Dictionary of Finnish dialects] ( $a-$ lysmä). 2012-. Kotimaisten kielten keskuksen verkkojulkaisuja 30. Helsinki: Kotimaisten kielten keskus. Updated 22 May 2019 [Accessed February 2015]. 〈http://kaino.kotus.fi/sms〉 
SMSA $=$ Suomen murteiden sana-arkisto [Archive of the Dictionary of Finnish dialects]. Helsinki: Kotimaisten kielten keskus. (See (in Finnish): 〈http://www.kotus.fi/aineistot/sana-aineistot/suomen_murteiden_ sana-arkisto >)

SSA = Itkonen, Erkki \& Ulla-Maija Kulonen (eds) 1992-2000: Suomen sanojen alkuperä. Etymologinen sanakirja [Origin of Finnish words. Etymological dictionary] 1-3. SKST 556, KKTKJ 62. Helsinki: SKS \& KKTK.

SVJa = Zajceva, M[aria] I. \& M[aria] I. Mullonen 1972: Slovar' vepsskogo jazyka [Dictionary of the Veps language]. Akademija Nauk SSSR. Karel'skij filial. Institut jazyka, literatury i istorii. Leningrad: Nauka.

VK = Vadja keele sõnaraamat. Vad'd'aa tšeelee sõna-tširja. Slovar'vodskogo jazyka [Dictionary of Vote]. 2013. 2., täiendatud ja parandatud trükk. Ed. Silja Grünberg. Tallinn: EKI. User interface 2019 available at: 〈http://www.eki.ee/dict/vadja/», PDF's of the dictionary available at the same address.

VKJo = Tsvetkov, Dmitri 1995: Vatjan kielen Joenperän murteen sanasto [Vocabulary of the Joenperä (Jõgõperä) dialect of Vote (with reverse vocabulary)]. Toimittanut, käänteissanaston ja hakemiston laatinut Johanna Laakso. LSFU XXV, KKTKJ 79. Helsinki: SUS \& KKTK.

$\mathrm{VKKu}=$ Posti, Lauri 1980: Vatjan kielen Kukkosin murteen sanakirja [Dictionary of the Kukkosi (Kukkuzi) dialect of Vote]. Ainekset kerännyt Lauri Posti. Painokuntoon toimittanut Seppo Suhonen Lauri Postin avustamana. LSFU XIX, KKTKJ 8. Helsinki: SUS \& KKTK.

$\mathrm{VKMa}=$ Kettunen, Lauri 1986: Vatjan kielen Mahun murteen sanasto [Vocabulary of the Mahu dialect of Vote]. Eds Jarmo Elomaa, Eino Koponen \& Leena Silfverberg. Castrenianumin toimitteita 27. Helsinki: Castrenianumin laitokset \& SUS.

VKS = Vadja keele sõnaraamat [Dictionary of Vote] 1-7. 1990-2011. Eds Elna Adler \& Merle Leppik (1-4), Silja Grünberg (5-7). Tallinn: EKI. VMS = Väike murdesõnastik [Shorter dialect dictionary (of Estonian)] III. 1982, 1989. Ed. Valdek Pall. Tallinn: Valgus. Väike murdesõnastik [User interface of the Shorter dialect dictionary of Estonian]. Tallinn: EKI. 〈http://www.eki.ee/dict/vms/〉

VVS = Vepsän verkkosanasto [Online vocabulary of Veps]. 2007. Helsinki: Kotimaisten kielten tutkimuskeskus. [Accessed June 2015.] 〈http:// kaino.kotus.fi/sanat/vepsa/> 
References

Aikio, Ante 2007: Etymological nativization of loanwords. A case study of Saami and Finnish. - Ida Toivonen \& Diane Nelson (eds), Saami Linguistics. Amsterdam studies in the theory and history of linguistic science. Series IV. Current issues in linguistic theory. Volume 288. Amsterdam. 17-52.

Aikio, Marjut 1988: Saamelaiset kielenvaihdon kierteessä. Kielisosiologinen tutkimus viiden saamelaiskylän kielenvaihdosta 1910-1980. [Saamis in the vortex of language shift. Sociolinguistic study of the language shift in five Saami villages in 1910-1980. PhD thesis.] SKST 479. Helsinki: SKS.

Äimä, Frans 1901: Ä̈̈neopillinen tutkimus Tytärsaaren murteesta [A phonological study on the dialect of Tytärsaari]. Vähäisiä kirjelmiä XXXI. Eripainos aikakauskirjasta Suomi (IV:1). Helsinki: SKS.

Ahlqvist, Aug[ust] 1856: Wotisk grammatik jemte språkprof och ordförteckning [Grammar of Vote with language samples and vocabulary]. Acta Societas Scientiarum Fennicae. Tomi qvinti. Fasciculus I. Helsingforsiae: Finska Vetenskaps-Societeten.

Alenius, Kari 2015: Language in education in Estonian Ingria between the World Wars. Presentation given at the Congressus Duodecimus Internationalis Fenno-Ugristarum, Oulu 2015. Abstract in the Book of abstracts. 430. Abstract available at: 〈https://www.oulu.fi/sites/default/ files/content/CIFU12-BookOfAbstracts_4.pdf)

$\mathrm{ALFE}=$ Atlas Linguarum Fennicarum 1-3. Itämerensuomalainen kielikartasto. Läänemeresoome keeleatlas. Ostseefinnischer Sprachatlas. Lingvističeskij atlas pribaltijsko-finskix jazykov. 2004-2010. Helsinki: SKS \& KKTK. Available at: 〈https://avaa.tdata.fi/web/avaa/-/kotus-kielikartastot〉

Ariste, Paul 1941: Vadja keelenäiteid [Vote language samples]. Acta et Commentationes Universitatis Tartuensis B 49-6. Tartu: Tartu Riiklik Ülikool.

1956: Läänemere keelte kujunemine ja vanem arenemisjärk [The development and the earlier stage of the Finnic languages]. - H[arri] Moora (ed.), Eesti rahva etnilisest ajaloost. Tallinn: Eesti NSV Teaduste Akadeemia Ajaloo Instituut. 5-23.

1957: Vatjalaisten nykyisyydestä [About the current situation of Votes]. - Virittäjä 61: 119-124.

1958: Vadja rahvajutte Mati külast [Vote folk tales from Mati village]. Keele ja Kirjanduse Instituudi uurimused II. Keelelisi küsimusi. Tallinn: Eesti NSV Teaduste Akadeemia \& Eesti Riiklik Kirjastus. 148-166. 
1962: Teiste Läänemere keelte elemente Vaivara murrakuis [Elements of other Finnic languages in Vaivara dialects]. - Emakeele Seltsi aastaraamat VIII: 11-18. Tallinn.

1965a: Vadja keele ja eesti murrete suhetest [On the relations of the Vote language and the Estonian dialects]. - Sõna sõna kõrvale. Paul Ariste teaduslikust tegevusest. Emakeele Seltsi toimetised 7. Tallinn. 106-110. [Published for the first time in German in 1963: Die Beziehungen des Wotischen zu den estnischen Mundarten. - Congressus Internationalis Fenno-Ugristarum I, Budapestini habitus 20.-24. IX.1960. Budapest. 212-215.]

1965b: Vadja kohanimedes [Vadja in place names]. - H[arri] Moora \& L[embit] Jaanits (eds), Slaavi-läänemeresoome suhete ajaloost. Tallinn: Eesti NSV Teaduste Akadeemia Ajaloo Instituut. 91-106.

1968: Welche Sprache spricht die ostseefinnische Bevölkerung in Vaipooli? - Fenno-ugrica. Juhlakirja Lauri Postin kuusikymmenvuotispäiväksi 17.3.1968. MSFOu 145. Helsinki: SUS. 12-19.

- 1977: Estonian and Karelian (Izhorian) language contacts. - Sovjetskoje Finno-Ugrovedenije XIII: 7-11.

_ 1981: Keelekontaktid. Eesti keele kontakte teiste keeltega [Language contacts. The contacts of Estonian with other languages]. Eesti NSV Teaduste Akadeemia Emakeele Seltsi toimetised 14. Tallinn: Valgus. 1987: Vadjalaste ja eestlaste kokkupuuteid [Connections between Votes and Estonians]. - Fenno-Ugristica 14. Uurali keelte sõnavara ja grammatiline ehitus. Tartu Riikliku Ülikooli toimetised 776. 21-31. 1998: Vadjalaste ja eestlaste suhteid 19. sajandil ja 20. sajandi alguses [Relations between Votes and Estonians in the $19^{\text {th }}$ century and the beginning of the $20^{\text {th }}$ century]. - Emakeele Seltsi aastaraamat 35-42 1989-1996: 14-21. Tartu.

2005: Vadja päevikud 1942-1980 [Vote diaries 1942-1980]. Ed. ErgoHart Västrik. Litteraria 22. Eesti kultuuriloo allikmaterjale. Tartu: Eesti Kirjandusmuuseum.

Björklöf, Sofia 2012: Viron rantamurteen länsiryhmän sanaston alkuperä suomalaislainojen valossa. [The origin of the vocabulary of the western subgroup of the Estonian Coast dialect in light of Finnish loanwords. Master's thesis.] Pro gradu -tutkielma. Helsingin yliopiston suomen kielen, suomalais-ugrilaisten ja pohjoismaisten kielten ja kirjallisuuksien laitos. Available at: 〈http://urn.fi/URN:NBN:fi-fe2012121410304〉 2017: Svenska lånord i den västra gruppen av estniska kustdialekter [Swedish loanwords in the western subgroup of the Estonian Coast dialect]. - Jan-Ola Östman, Caroline Sandström, Pamela Gustavsson \& Lisa 
Södergård (eds), Ideologi, identitet, intervention. Nordisk dialektologi 10. Nordica Helsingiensia 48. Dialektforskning 5. Helsingfors: Helsingfors universitet; Nordica vid Finska, finskugriska och nordiska institutionen. 369-394. Available at: 〈http://hdl.handle.net/10138/224299〉

2018: Uusia lainaetymologioita viron koillisrannikon rantamurteen länsiryhmässä [New loan etymologies in the western subgroup of the Estonian Coast dialect of the northeastern coast]. - Sampsa Holopainen

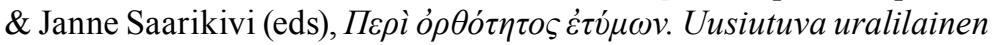
etymologia. Uralica Helsingiensia 11. Helsinki: SUS. 357-487. Available at: 〈https://journal.fi/uralicahelsingiensia/issue/view/uh11/489〉

EES = Metsmägi, Iris, Meeli Sedrik \& Sven-Erik Soosaar 2012: Eesti etümoloogiasõnaraamat [Estonian etymological dictionary]. Tallinn: EKI \& Eesti Keele Sihtasutus. User interface available at: «http://www. eki.ee/dict/ety/>

Elomaa, Jarmo 1989: Vatjan astevaihtelu ja vatjan ja inkeroisen kontaktit - erityisesti erään inkeroislähtöisen vatjalaisidiolektin näkökulmasta tarkasteltuna. [Vowel harmony in Vote and the contacts of Vote and Ingrian - especially from the point of view of one idiolect of Vote with an Ingrian origin. Licenciate thesis.] Helsingin yliopiston itämerensuomalaisten kielten laitos.

Ernits, Enn 2005: Vadja keele varasemast murdeliigendusest ja hilisemast hääbumisest [On the earlier dialect division and the later extinction of Vote]. - Karl Pajusalu \& Jan Rahman (eds), Piirikultuuriq ja -keeleq. Piirikultuurid ja -keeled. Võro Instituudi toimõndusõq 17. Võro: Võro Instituut'. 76-90, 183-184. Available at: 〈https://wi.ee/et/voruinstituudi-toimetised-17/>

2007: Isurite asualadest ja algkodust [About the residential districts and the cradle of the Ingrians]. - Helen Koks \& Jan Rahman (eds), Õdagumeresoomõ kodo. Läänemeresoome kodu. Võro Instituudi toimõndusõq 20. Võro: Võro Instituut'. 13-32, 175-176. Available at: 〈https://wi.ee/et/voru-instituudi-toimetised-20/〉

Grünthal, Riho 1997: Livvistä liiviin. Itämerensuomalaiset etnonyymit [From Olonets Karelian to Livonian. Finnic ethnonymes]. CT 51. Helsinki: Suomalais-ugrilainen laitos \& SUS.

(forthcoming): Inkeroisen kieli [Ingrian language]. - Lassi Saressalo, Kati Kallio \& Riho Grünthal (eds), Inkerikot, setut ja vatjalaiset. Helsinki: SKS.

Hakamies, Pekka 1991: Inkeri monietnisenä alueena [Ingria as a multiethnic area]. - Pekka Nevalainen \& Hannes Sihvo (eds), Inkeri. Historia, kansa, kulttuuri. SKST 547. Helsinki: SKS. 197-204. 
Härmävaara, Hanna-Ilona 2013: Kielten samankaltaisuus monikielisen suomalais-virolaisen vuorovaikutuksen resurssina [Cross-linguistic similarities as a resource of multilingual interaction between Finns and Estonians]. - Annekatrin Kaivapalu (ed.), Lähivõrdlusi. Lähivertailuja 23. Tallinn: Eesti Rakenduslingvistika Ühing. 60-88. Available at: 〈http://dx.doi.org/10.5128/LV23.03〉

2014: Facilitating mutual understanding in everyday interaction between Finns and Estonians. - Applied Linguistics Review 5/1: 211245. [Special issue on Receptive multilingualism.] Available at (subject to a charge): 〈https://doi.org/10.1515/applirev-2014-0010〉

2017: Official language policy as a factor in using receptive multilingualism among members of an Estonian and a Finnish student organization. - Maarja Siiner, Kadri Koreinik \& Kara D. Brown (eds), Language policy beyond the state. Language Policy 14. Cham: Springer. 201-221. Available at (subject to a charge): 〈http://dx.doi. org/10.1007/978-3-319-52993-6_11>

(forthcoming): Building the bridge in interaction - receptive multilingualism among Finns and Estonians. [PhD thesis.] University of Helsinki.

Heinsoo, Heinike 1998: Vadjalased ja vadja keele kujunemine [Votes and the development of the Vote language]. - Jaan Õispuu \& Marje Joalaid (eds), Kaheksa keelt, kaheksa rahvast. Tallinn: Tallinna Pedagoogikaülikool. 14-29.

Junttila, Santeri 2015: Tiedon kumuloituminen ja trendit lainasanatutkimuksessa. Kantasuomen balttilaislainojen tutkimushistoria. [Accumulation of information and tendencies in the study of loanwords. Research history of Baltic loans in Proto-Finnic. PhD thesis.] Helsinki: Helsingin yliopisto. Available at: 〈http://urn.fi/URN:ISBN:978-951-51-1842-4〉

Jussila, Raimo (ed.) 1991: Suomen murteiden aineslähteitä [Material sources on Finnish dialects]. KKTKJ 57. Helsinki: KKTK \& VAPK-kustannus.

Kettunen, Lauri 1915: Vatjan kielen äännehistoria [Sound history of Vote]. Suomi IV:15. Helsinki: SKS.

1930 [1915]: Vatjan kielen äännehistoria [Sound history of Vote]. Toinen, uusittu painos. SKST 185. Helsinki: SKS.

1945: Tieteen matkamiehenä. Kaksitoista ensimmäistä retkeä 19071918 [A scientific explorer. My first twelve trips 1907-1918]. Helsinki: Werner Söderström.

1957: "Isuri keel" [“Izhorian language"]. - Virittäjä 61: 124-133.

Kokko, Ossi 2007: Inkerinsuomen pirstaleisuus. Eräiden sijojen kehitys murteen yksilöllistymisen kuvastajana. [Scattered Ingrian Finnish. 
The development of selected cases as reflectors of the individualisation of a dialect. $\mathrm{PhD}$ thesis.] Joensuun yliopiston humanisisia julkaisuja 48. Joensuu: Joensuun yliopisto, humanistinen tiedekunta. Available at: 〈http://urn.fi/URN:ISBN:978-952-219-036-9〉

Köppen, Peter v[on] 1867: Erklärender Text zu der ethnographischen Karte des St. Petersburger Gouvernements. St. Petersburg: Kaiserliche Akademie der Wissenschaften.

Köppen, Peter von (ed.) 1849 = Koeppen, P. v. (ed.) 1849: Ethnographische Karte des Peterburgischen Gouvernements. St. Petersburg: Kaiserliche Akademie der Wissenschaften.

Krjukov, Aleksej 1993 [1987]: Ingermanland och ingermanländarna [Ingria and Ingrians. Translated from Finnish into Swedish by Sulo Huovinen]. - Sulo Huovinen (ed.), Ingermanland - om land och folk. Stockholm: Kulturfonden för Sverige och Finland. 19-32. [Published for the first time in Finnish in 1987: Inkerinmaa ja inkeriläiset. - Punalippu 8/1987: 123-130.]

Krohn, Julius 1901: Kantelettaren tutkimuksia [Studies on Kanteletar] 2. Toimittanut ja täydentänyt Kaarle Krohn. SKST 95. Helsinki: SKS.

Kuznetsova, Natalia, Elena Markus \& Mehmet Muslimov 2015: Finnic minorities of Ingria. The current sociolinguistic situation and its background. - Heiko Marten, Michael Rießler, Janne Saarikivi \& Reetta Toivanen (eds), Cultural and linguistic minorities in the Russian Federation and the European Union. Multilingual Education 13: Comparative studies on equality and diversity. Berlin: Springer. 127-167. Available at (subject to a charge): 〈https://www.springer.com/gp/book/9783319104546〉

Laanest, Arvo 1961: Isuri murrete rühmitamisest [On dividing the Ingrian dialects]. - Keele ja Kirjanduse Instituudi uurimused VI. Keele, kirjanduse ja rahvaluule küsimusi. Tallinn: Eesti NSV Teaduste Akadeemia \& Eesti Riiklik Kirjastus. 200-216.

1964: Isurid ja isuri keel - meie lähemaid sugulaskeeli [Ingrians and the Ingrian language - one of our most closely related languages]. Tallinn: Eesti NSV Teaduste Akadeemia Keele ja Kirjanduse Instituut.

1970: Kes on isurid? - Aino Valmet, Paula Palmeos \& Juhan Peegel (eds), Saaremaast Sajaanideni ja kaugemalegi. Tallinn: Kirjastus Valgus. 100-110.

1988: Vatjan sanaston suhteista lähisukukieliin [On lexical relations of Vote with closely related languages]. - Symposium 1988. Itämerensuomalaisen filologian symposiumi, Turku 30.8.-2.9.1988. Referaatit. Turku: Turun yliopiston suomalaisen ja yleisen kielitieteen laitos, Finska institutionen vid Åbo Akademi, Suomen ja Neuvostoliiton välinen tieteellis-teknillinen yhteistoimintakomitea. 48. 
Lauerma, Petri 1993: Vatjan vokaalisointu. [Vowel harmony of Vote. PhD thesis.] MSFOu 214. Helsinki: SUS.

Leppik, Merle 1975: Ingerisoome Kurgola murde fonoloogilise süsteemi kujunemine [Development of phonological system in the Ingrian Finnish Kurkola dialect]. Tallinn: Eesti NSV Teaduste Akadeemia Keele ja Kirjanduse Instituut.

Leskinen, Heikki 1991: Inkerin kielimuodot [The language varieties of Ingria]. - Pekka Nevalainen \& Hannes Sihvo (eds), Inkeri. Historia, kansa, kulttuuri. SKST 547. Helsinki: SKS. 222-233.

— 1995: Inkerin asutus ja väestöryhmät [The inhabitants and ethnic groups of Ingria]. - Mauno Jokipii (ed.), Itämerensuomalaiset. Heimokansojen historiaa ja kohtaloita. Jyväskylä: Atena Kustannus. 163173.

Lindstedt, Jouko 2000: Linguistic balkanization: contact-induced change by mutual reinforcement. - Dicky Gilbers, John Nerbonne \& Jos Schaeken (eds), Languages in contact. Studies in Slavic and General Linguistics, vol. 28. Amsterdam: Rodopi. 231-246. Available at (subject to a charge): 〈https://brill.com/view/title/30810〉

Mäger, Mart 1967: Eesti linnunimetused [Bird names in Estonian]. Ed. Valdek Pall. Tallinn: Eesti NSV Teaduste Akadeemia Keele ja Kirjanduse Instituut.

Mägiste, Julius 1925: Rosona (Eesti Ingeri) murde pääjooned [Main characteristics of the Rosona (Estonian Ingria) dialect]. Tartu.

_ 1927: Paarist vadja laenust eesti keeles [On a couple of Vote loans in Estonian]. - Eesti Kirjandus 21: 161-162. Eesti Kirjanduse Selts.

Markus, Elena \& Fedor Rozhanskiy 2010: Asymmetry in Votic-Ingrian language contacts. - SLE 2010: 43 ${ }^{\text {rd }}$ Annual meeting of the Societas Linguistica Europaea, Vilnius University, Lithuania, 2-5 September 2010. Book of abstracts. 141.

Markus, E[lena] B. \& F[edor] I. Rozhanskiy 2011a: Sovremennyj vodskij jazyk. Teksty i grammatičeskij očerk. V 2-h tomah. [Contemporary Vote. Texts and grammar. In 2 volumes.] Sankt-Peterburg: NestorIstorija.

Markus, Elena \& Fedor Rozhanskiy 2011b: The development of a mixed language in the multilingual environment (evidence from the Kukkuzi dialect). - Uralic languages and multilingualism: contexts and manifestations in a language family 2-3 June, 2011. Abstract available at: 〈https://www.slm.uni-hamburg.de/ifuu/download/konferenzen/markusrozhanskiy.pdf〉 
2012: Votic or Ingrian: new evidence on the Kukkuzi variety. - Finnisch-Ugrische Mitteilungen 35: 77-94. Available at (subject to a charge): 〈https://buske.de/finnisch-ugrische-mitteilungen-band-35-9607.html〉 2013: Correlation between social and linguistic parameters in modeling language contact: evidence from endangered Finnic varieties. International Journal of the Sociology of Language 221: 53-76. Available at (subject to a charge): 〈https://doi.org/10.1515/ijsl-2013-0023〉

Marttila, Annu 2010: A cross-linguistic study of lexical iconicity and its manifestation in bird names. [PhD thesis.] Helsinki: University of Helsinki.

Muslimov, Mehmed Zakirovitš 2005: Jazykovye kontaktyv Zapadnoj Ingermanlandii (nižnee tečenie reki Lugi). [Language contacts in Ingria (the lower course of the Luga River). PhD thesis.] Sankt-Peterburg: Institute for Linguistic Studies of the Russian Academy of Sciences.

Muslimov, M[ehmed] Z. 2009: K klassifikacii finskix dialektov Ingermanlandii [On classification of the Finnish dialects in Ingria]. - Sergej Myznikov \& Igor' Brodskij (eds), Voprosy uralistiki 2009. Naučnyj al'manax. Sankt-Peterburg: Nauka. 179-204.

Muslimov, Mehmet 2015: Moloskovitsa dialect in Western Ingria. Presentation given at the Congressus Duodecimus Internationalis FennoUgristarum, Oulu 2015. Abstract in the Book of abstracts. 204-205. Abstract available at: 〈https://www.oulu.fi/sites/default/files/content/ CIFU12-BookOfAbstracts_4.pdf>

Must, Mari 2000: Vene laensõnad eesti murretes [Russian loanwords in Estonian dialects]. Tallinn: Eesti Keele Sihtasutus.

Nirvi, Ruben E[rik] 1961: Inkeroismurteiden asema [The position of Ingrian dialects]. - Kalevalaseuran vuosikirja 41: 99-132. Helsinki: WSOY.

Oja, Vilja 2005: Sõna põll taustast [On the background of the word põll]. Keel ja Kirjandus XLVIII: 475-480.

Ojansuu, Heikki 1916: Suomen kielen tutkimuksen työmaalta. Sarja esitelmiä I [From the field of study of the Finnish language. A series of presentations I]. Suomalais-virolaiset kielelliset kosketukset [Finnish-Estonian language contacts]. 98-202. Jyväskylä: Gummerus.

Pajusalu, Karl 1999: Eesti murded ja murderühmad [Estonian dialects and dialect groups]. - Emakeele Seltsi aastaraamat 43: 64-98. Tartu.

Pajusalu, Karl, Tiit Hennoste, Peeter Päll \& Jüri Viikberg 2009: Eesti murded ja kohanimed [Estonian dialects and place names]. 2., täiendatud trükk, toim. Tiit Hennoste. Tallinn: Tartu Ülikooli eesti ja üldkeeleteaduse instituut \& EKI. 
Pajusalu, Karl, Péter Pomozi, Dezső Juhász \& Tiit-Rein Viitso 2012: Sociolinguistic comparison of the development of Estonian and Hungarian dialect areas. - Linguistica Uralica XLVIII: 241-264. Available at: 〈http://dx.doi.org/10.3176/lu.2012.4.01〉

Pall, Valdek 1969: Põhja-Tartumaa kohanimed [Place names in Northern Tartumaa] 1. Ed. M[adis] Norvik. Tallinn: Valgus.

— 1970: Maahanmuuton jälkiä Pohjois-Tartumaan paikannimissä [Traces of immigration in the place names of Northern Tartumaa]. - Virittäjä 74: 12-22.

— 1977: Põhja-Tartumaa kohanimed [Place names in Northern Tartumaa] 2. Ed. M[adis] Norvik. Tallinn: Valgus.

Pasanen, Annika 2015: Kielipesiä, kielimestareita ja kieli-ideologioita. Inarinsaamen kielen revitalisaatio [Language nests, language masters, and language ideologies. The revitalisation of Inari Saami]. Presentation in the Finno-Ugrian Society, 18 September 2015.

Paulaharju, Marjut (ed.) 2010: Samuli Paulaharjun Inkeri [Samuli Paulaharju's Ingria. Edited articles about the journey to Ingria in the summer of 1911 written by S. Paulaharju]. SKST 1292. Helsinki: SKS.

Porkka, Volmari 1885: Ueber den Ingrischen Dialekt mit Berücksichtigung der übrigen finnisch-ingermanländischen Dialekte. Helsingfors: J. C. Frenckell \& Sohn.

Posti, Lauri 1970: Eesti põlle algupärast [On the origin of the Estonian põll]. - Keel ja Kirjandus XIII: 470-472.

Randefelt, Roland 1992: Inkeri / Ингерманландия / Ingermanland / Ingria / Ingeri: tiekartta / карта дорог / vägkarta / Straßenkarte / road map / teede kaart. $1: 200000$.

Riionheimo, Helka 2007: Muutoksen monet juuret. Oman ja vieraan risteytyminen Viron inkerinsuomalaisten imperfektinmuodostuksessa. [Multiple roots of change. Mixing native and borrowed influence in the past tense formation by Ingrian Finns. PhD thesis.] SKST 1107. Helsinki: SKS.

2013: Kieltenvälinen vertailu kielikontaktitutkimuksessa [Comparing between languages in the study of language contact]. - Leena Kolehmainen, Matti Miestamo \& Taru Nordlund (eds), Kielten vertailun metodiikka. SKST 1387. Helsinki: SKS. 219-250.

Rozhanskiy, F[edor] I. \& E[lena] B. Markus 2013: O statuse nižnelužskogo dialekta ižorskogo jazyka sredi rodstvennyx idiomov [On the status of Lower Luga Ingrian among related varieties]. - Lingvističeskij bespre$d e l-2$. Sbornik naučnyx trudov k jubileju A. I. Kuznetsovoj. Moskva: Moscow University Press. 219-232. 
Rozhanskiy, Fedor \& Elena Markus 2014: Lower Luga Ingrian as a convergent language. Presentation given at the FINKA Symposium. On the border of language and dialect. University of Eastern Finland, Joensuu, 4-6 June, 2014. Handout of the presentation; abstract in Abstracts. 36-37.

2019: A new resource for Finnic languages: The outcomes of the Ingrian documentation project. - Sofia Björklöf \& Santra Jantunen (eds), Multilingual Finnic. Language contact and change. Uralica Helsingiensia 14. Helsinki: SUS. 303-326. Available at: 〈https://doi. org/10.33341/uh.85039>

Saareste, Andrus 1952: Kaunis emakeel. Vesteid eesti keele elust-olust [Beautiful mother tongue. Discussions about Estonian]. Lund: Eesti Kirjanike Kooperatiiv.

Salminen, Tapani 2010: Huomioita lintujen nimityksistä [Observations on bird names]. - Sirkka Saarinen, Kirsti Siitonen \& Tanja Vaittinen (eds), Sanoista kirjakieliin. Juhlakirja Kaisa Häkkiselle 17. marraskuuta 2010. MSFOu 259. Helsinki: SUS. 343-358.

Saloheimo, Veijo 1991: Inkerinmaan asutus ja väestö 1618-1700 [The settlement and inhabitants of Ingria in 1618-1700]. - Pekka Nevalainen \& Hannes Sihvo (eds), Inkeri. Historia, kansa, kulttuuri. SKST 547. Helsinki: SKS. 67-82.

Savijärvi, Ilkka 1996a: Länsi-Inkerin heimot, kielet ja murteet [The tribes, languages, and dialects of western Ingria]. - Ilkka Savijärvi, Muusa Savijärvi \& Janne Heikkinen (eds), Vot, ihminen tahtoo kotimaalle. Länsi-Inkerin kieltä ja kohtaloita. Studia Carelica Humanistica 8. Joensuu: Joensuu University Press. 7-17.

1996b: Western Ingria - where languages and dialects meet. - Ilkka Savijärvi, Muusa Savijärvi \& Janne Heikkinen (eds), Vot, ihminen tahtoo kotimaalle. Länsi-Inkerin kieltä ja kohtaloita. Studia Carelica Humanistica 8. Joensuu: Joensuu University Press. 183-188.

1998: Cognate languages in contact. Ingria - where four Baltic-Finnic languages meet. - Jussi Niemi, Terence Odlin \& Janne Heikkinen (eds), Language contact, variation, and change. Studies in Languages 32. Joensuu: Joensuun yliopisto. 269-286.

2001: Lähisukukielet kontaktissa [Closely related languages in contact].

- Congressus Nonus Internationalis Fenno-Ugristarum 7.-13.8.2000

Tartu. Pars VI: Dissertationes sectionum Linguistica III. Tartu. 161-166. Setälä, E[mil] N[estor] 1964: E. N. Setälän vatjalaismuistiinpanot. Les notes d'E. N. Setälä sur la langue vote. Rédigées et publicées par les soins de Lauri Posti et de Seppo Suhonen. - Memoria saecularis E. N. Setälä 27.II.1964. MSFOu 135. Helsinki: SUS. 
SKES = Toivonen, Y. H., Erkki Itkonen, Aulis J. Joki \& Reino Peltola 19551981: Suomen kielen etymologinen sanakirja [Etymological dictionary of Finnish] I-VII. LSFU XII. Sanahakemiston (VII) koostaneet Satu Tanner ja Marita Cronstedt. Helsinki: SUS.

Söderman, Tiina 1996: Lexical characteristics of the Estonian North Eastern Coastal dialect. [PhD thesis.] Studia Uralica Upsaliensia 24. Acta Universitatis Upsaliensis. Uppsala.

Sovijärvi, Antti 1944: Foneettis-äännehistoriallinen tutkimus Soikkolan inkeroismurteesta [Phonetic-soundhistorical study on the Ingrian dialect of Soikkola]. Suomi-sarjan eripainoksia 5. Uusi sarja. Helsinki: SKS.

SSA = Itkonen, Erkki \& Ulla-Maija Kulonen (eds) 1992-2000: Suomen sanojen alkuperä. Etymologinen sanakirja [Origin of Finnish words. Etymological dictionary] 1-3. SKST 556, KKTKJ 62. Helsinki: SKS \& KKTK.

Suhonen, Seppo 1979: Über die Beziehungen zwischen den Finnischen u. d. Estnischen Küstdialekten. - Erhard F. Schiefer (ed.), Explanationes et tractationes Fenno-Ugricae in honorem Hans Fromm. Münchener Universitäts-Schriften. München. 357-366.

1985: Wotisch oder Ingrisch? - Dialectologia Uralica: Materialen des ersten Internationalen Symposions zur Dialektologie der uralischen Sprachen 4.-7. September 1984 in Hamburg. Veröffentlichungen der Societas Uralo-Altaica. Band 20. Herausgegeben von Wolfgang Veenker. Wiesbaden: Otto Harrassowitz. 139-148.

1986: Zur Identifizierung der jungen Lehnwörter im Wotischen. Lyökämme käsi kätehen. Beiträge zur Sprachkontaktforschung im Bereich des Finnougrischen und des Germanischen A. D. Kylstra zum 65. Geburtstag. Amsterdam: Rodopi. 151-161.

2000: Kirderannikumurde suhted naaberkeeltega [Relations of the (Estonian) Northeastern Coastal dialects with neighbouring languages]. - Jüri Viikberg (ed.), Inter dialectos nominaque. Pühendusteos Mari Mustale 11. novembril 2000. Eesti Keele Instituudi toimetised 7. Tallinn: EKI. 362-374.

Talve, Ilmar 1990: Matka vatjalaisiin 1942 [Trip to the Votes in 1942]. Pekka Laaksonen \& Sirkka-Liisa Mettomäki (eds), Inkerin teillä. Kalevalaseuran vuosikirja 69-70. Helsinki: SKS. 46-66.

Teinonen, Markku \& Timo J. Virtanen (eds) 1999: Ingrians and neighbours. Focus on the eastern Baltic Sea region. Studia Fennica Ethnologia 5. Helsinki: SKS. 
Toikka, Kaja 2003: Kirderannikumurde idaosa murde- ja keelekontaktid. [Dialect and language contacts in the eastern part of the (Estonian) Northeastern Coastal dialects. Printed master's thesis.] Tallinna Pedagoogikaülikooli läänemeresoome keelte õppetool.

Tsvetkov, Dimitri 1925: Vadjalased [The Votes]. - Eesti Keel IV: 39-44.

Vaba, Lembit 1977: Läti laensõnad eesti keeles [Latvian loanwords in Estonian]. Tallinn.

1997: Uurimusi läti-eesti keelesuhetest. [Studies on Latvian-Estonian language relations. PhD thesis.] Tallinn - Tampere: EKI \& Tampereen yliopiston suomen kielen ja yleisen kielitieteen laitos.

2014: Levik kui etümoloogiline kriteerium (eeskätt eesti sõnavara näitel) [Areal distribution as an etymological criterion (mainly on the example of Estonian lexis)]. - Keel ja Kirjandus LVII: 700-707. Available at: 〈http://kjk.eki.ee/ee/issues/2014/8-9/541〉

2015: Sõna sisse minek ["Going in to the word". Collection of articles 1989-2015]. Emakeele Seltsi toimetised 73. Tallinn: Eesti Teaduste Akadeemia Emakeele Selts.

Viitso, Tiit-Rein 1993: Tutkimus vatjan vokaalisoinnusta [A study on the vowel harmony of Vote. Review: Petri Lauerma, Vatjan vokaalisointu]. - Virittäjä 97: 522-526.

Wiedemann, Ferdinand Johann 1893 [1869]: Ehstnisch-deutsches Wörterbuch. Zweite vermehrte Auflage. Redigirt von Jacob Hurt. St. Petersburg: der Kaiserlichen Akademie von Wissenschaften. 
Itämerensuomen varieteettien keskinäiset

kontaktit ja sanastolliset suhteet

Länsi-Inkerissä ja Koillis-Virossa

\section{Sofia Björklöf}

Länsi-Inkerin ja Koillis-Viron historiallinen kielikontaktitilanne heijastuu alueen kielten sanastossa eri tavoin. Lähemmin tarkasteltavat kielimuodot ovat viron koillisrannikkomurteet ${ }^{28}$, viron itämurteet, vatjan murteet, inkeroismurteet sekä Inkerin suomalaismurteet. Kaikki nämä kielimuodot ovat geneettisesti läheisiä itämerensuomalaisia varieteetteja.

Vatjan ja inkeroisen perinteiset puhuma-alueet sijaitsivat LänsiInkerissä, Suomenlahden kaakkoisrannikolla Narvajoen ja nykyisen metropolin, Pietarin, välisellä alueella. Pietari rakennettiin itämerensuomalaisten ikivanhalle kauppapaikalle 1700-luvun alussa. Paikallinen väestö ei koskaan ole muodostanut omaa valtiota, vaan aluetta ovat hallinneet Venäjä ja Ruotsi. 1600-luvulla Inkeriin muutti suomenpuhujia ja venäläisten migraatio kasvoi huomattavasti Pietarin vuonna 1703 tapahtuneen perustamisen jälkeen. Lopulta virolaiset tulokkaat asettuivat samalle alueelle 1800-luvulla. Länsi-Inkerissä oli lisäksi saksan- ja todennäköisesti myös ruotsinpuhujia.

Uusien asukkaiden saapuminen poliittisesti hallitsevilta alueilta muutti Inkerin väestörakennetta, lisäsi kielellistä diversiteettiä, muutti kielten välistä hierarkiaa ja johti asteittain Inkerin kanta-asukkaiden kielen ja identiteetin vaihtoon. Sekä vatjan että inkeroisen puhujat olivat monikielisiä ja joissain kylissä oli seka-asutusta. Yleisesti ottaen varieteettien väliset rajat vanhoissa maalaisyhteisöissä ovat olleet hyvin häilyviä: vatjan ja inkeroisen puhujat ovat toistuvasti ilmaisseet mielipiteenään, että heidän murteensa ovat saman kielen murteita.

Tässä artikkelissa kuvaan yhtäältä Inkerinmaan historiallista sosiolingvististä tilannetta, toisaalta Inkerin historiallista kielikontaktitilannetta. Artikkelin sanasto-osuus pohjautuu vanhoihin murremateriaaleihin, jotka on julkaistu sanakirjoissa, sekä viron osalta edelleen osin julkaisemattomaan, arkistossa säilytettävään materiaaliin. Sanat, joita analysoin etymologisesti, esiintyvät vatjassa, inkeroisessa ja

28. Termin valinnasta ks. Björklöf (2018: 363). 
virossa. Päähypoteesini on, että tutkimallani alueella on paljon keskinäisten kontaktien ja alueellisen diffuusion tuloksena saatuja lainasanoja, vaikka läheisten sukukielten tapauksessa lainaamisen suuntaa on usein vaikea todistaa. Lainasanat tarkentavat kuvaa sellaisten läheisten sukukielten keskinäisistä suhteista, joiden kehitystä ei voi kuvata yksin perinteisen binaarisen sukupuumallin keinoin. Esitän esimerkkejä vatjan, inkeroisen, viron ja suomen murteiden välisestä lainautumisesta (virosta on lainattu sanat trehvama 'tavata; osua; sattua', põll 'esiliina', hulkuma 'kuljeskella', suomesta heikko, kiuru, raju, höyry ja vatjasta ilata 'siivota'). Näiden esimerkkitapausten avulla kuvaan läheisten sukukielten välisen lainautumisen tutkimisen metodia. Osa julkaistavista etymologioista on uusia. Virolaiset lainat vatjassa ja inkeroisessa ovat tavallisesti tunnistettavissa pienen levikkinsä perusteella. Laina-alkuperää olevasta vatjan, inkeroisen ja viron yhteisestä sanastosta suurin osa taas on peräisin suomesta. Sekä vatjassa että virossa esiintyvillä lainoilla on usein inkeroisen lisäksi levikki suomessa, joten kahden viimemainitun äänteellisen samankaltaisuuden takia varmaa lainanantajakieltä on tavallisesti mahdoton määritellä. Vatjasta inkeroiseen ja viroon on saatu vain yksittäisiä lainoja, jotka saattavat olla myös substraattia. 
Läänemeresoome keelte omavahelised kontaktid ja sõnavara seosed Lääne-Ingeris ja Kirde-Eestis

\section{Sofia Björklöf}

Lääne-Ingerimaa ja Kirde-Eesti ajaloolised keelekontaktid peegelduvad selle geograafilise ala keelte sõnavaras erinevatel viisidel. Käesolevas artiklis vaadeldakse lähemalt eesti kirderannikumurdeid, eesti idamurdeid, vadja keele murdeid, isuri keele murdeid ning Ingerimaa soome keele murdeid. Mainitud keelekujud on ajalooliselt lähedased läänemeresoome sugulaskeeled.

Vadja ja isuri keele kõnelejate traditsioonilised alad asusid Lääne-Ingeris, Soome lahe kagukaldal Narva jõe ja praeguse Peterburi vahelisel alal. Peterburi rajati läänemeresoomlaste igivanale kauplemiskohale 18. sajandi alguses. Kohalik rahvas pole kunagi moodustanud enda oma riiki, vaid allus ala hõivanud Venemaale ja Rootsile. 17. sajandil asus Ingerisse elama sisserändajatena põhjapoolt soome keele kõnelejaid. Ka venelaste migratsioon kasvas märgatavalt peale Peterburi asutamist 1703. aastal. Viimastena asusid 19. sajandil Ingerimaale uustulnukatena ka eestlastest migrandid. Peale eelmiste on Lääne-Ingeris elanud ka saksa keele ning tõenäoliselt ka rootsi keele kõnelejaid.

Uute elanike saabumine poliitiliselt juhtivatest riikidest muutis Ingerimaa rahvastikku, kaasates keelelist mitmekesisust. Tekkinud olukord muutis keelte vahelist hierarhiat ja viis järk-järgult Ingeri põliselanike keele ja identiteedi assimileerumiseni. Nii vadja kui ka isuri keele kõnelejad olid kaua aega mitmekeelsed. Osades külades oli segaasustus. Üldiselt on keelte vahelised piirid vanades põllumajandusühiskondades olnud väga hägusad. Näiteks on vadja ja isuri keele kõnelejad korduvalt väljendanud arvamust, et nende murded on ühe ja sama keele murded.

Käesolevas artiklis kirjeldatakse Ingerimaa ajaloolist sotsiolingvistilist olukorda ja Lääne-Ingeri ajaloolisi keelekontakte. Artiklis vaadeldavad sõnad põhinevad vanadel murdematerjalidel, mis on avaldatud sõnaraamatutes. Peale selle analüüsitakse ka arhiivides leiduvaid avaldamata eestikeelseid sõnu. Etümoloogiliselt analüseeritakse lähemalt sõnu, mis esinevad nii vadja, isuri kui ka eesti keeles. 
Peamiseks hüpoteesiks on, et on võimalik leida omavaheliste kontaktide tulemusena levinud laensõnu, kuigi lähedaste sugulaskeelte puhul laenamise suunda on tihtipeale raske tõestada. Laensõnad täpsustavad pilti lähedaste sugulaskeelte vahelistest kontaktidest, mille arengut ei saa üksnes traditsionaalse binaarse sugupuuga kirjeldada. Näiteid tuuakse vadja, isuri, eesti ja soome murrete omavahelise sõnade laenamise kohta (eesti keelest on laenatud sõnad trehvama, põll, hulkuma, soome keelest heikko 'nõrk', kiuru 'lõoke', raju 'metsik; äge', mis esineb ka liitsõnades rajuilma, rajumyrsky 'torm', höyry 'aur' ning vadja keelest on laenatud ilata 'koristama'). Nende näidete abil kaalutakse ka metoodiliselt lähedaste sugulaskeelte vahelist laenamisprotsessi. Artiklis avaldatud etümoloogiatest osad on uued. Eesti laenud vadja ja isuri keeles on tavaliselt tuvastatavad oma kitsama levila alusel. Seevastu suurem osa laenatud sõnavarast, mis on ühine vadja, isuri ja eesti keelele, on pärit soome keelest. Nii vadja kui ka eesti keeles esinevaid laene tuntakse tavaliselt peale isuri ka soome keeles. Kuna kahe viimase häälikuline ülesehitus on sarnane, on kindlat laenuandjakeelt tihtipeale võimatu määratleda. Vadja keelest isuri ja eesti keelde on saadud ainult üksikuid laene, mille puhul võib olla tegemist ka substraadiga. 